\title{
Reintroducing DMPA to the Philippine Family Planning Program: A longitudinal study of continuing users and drop-outs
}

Population Council

Follow this and additional works at: https://knowledgecommons.popcouncil.org/departments_sbsr-rh

Part of the Demography, Population, and Ecology Commons, Health Services Research Commons, International Public Health Commons, and the Women's Health Commons

How does access to this work benefit you? Let us know!

\section{Recommended Citation}

"Reintroducing DMPA to the Philippine Family Planning Program: A longitudinal study of continuing users and drop-outs. Final Report," Special Report. Manila: Population Council, Department of Health, Manila and Family Planning Operations Research and Training Program (FPORTP), 1996. 
REINTRODUCING DMPA TO THE PHILIPPINE FAMILY PLANNING PROGRAM:

\author{
A Longitudinal Study of Continuing Users \\ and Drop-Outs
}

\title{
PHILIPPINES
}

FINAL REPORT

USAID Contract No. DPE-3030-Q-00-0023-00

Strategies for Improving Family Planning Service Delivery

\section{FAMILY PLANNING OPERATIONS RESEARCH AND TRAINING (FPORT) PROGRAM}

The Population Council, Manila in collaboration with the Department of Health

\section{ASIA \& NEAR EAST OPERATIONS RESEARCH AND TECHNICAL ASSISTANCE PROJECT}




\section{ACKNOWLEDGEMENTS}

This study was made possible with support from The Population Council's Asia and Near

East Operations Research and Technical Assistance (ANE OR/TA) Project. The ANE OR/TA Project is funded by the United States Agency for International Development, Office of Population, Health and Nutrition, under Contract No. DPE-3030-Q-00-0023-00, Strategies for Improving Family Planning Service Delivery.

The DMPA research team wishes to acknowledge the following individuals and institutions for their valuable contributions to this study:

1.) the Department of Health (DOH), Office of Special Concerns under the leadership of Dr. Carmencita Reodica and the DOH Family Planning Service, under the supervision of Dr. Rebecca Infantado;

2.) the regional, provincial and city family planning coordinators, health and population officers, service providers and DOH staff of Baguio City, Quezon City, Pangasinan, Laguna, Cebu, Davao del Sur, Davao City, Surigao del Sur and South Cotabato;

3.) the Social Development Research Center (SDRC) of De La Salle University under the guidance of Dr. Trinidad Osteria; the Social Research Office (SRO) of Ateneo de Davao University, under the supervision of Prof. Marlina Lacuesta, and the research staff of the Research Institute for Mindanao Culture (RIMCU) of Xavier University, under the supervision of Prof. Lita Sealza, who were responsible for data collection and data processing; and

4.) the 899 women from the sampled health facilities who generously gave their time to serve as respondents to the survey.

This report was collaboratively prepared by Myra Arenas (Population Council, Manila); Dr. Josefina Cabigon of the (Population Institute, University of the Philippines); and Dr. Marilou Palabrica-Costello (Population Council, Manila). 


\section{TABLE OF CONTENTS}

ACKNOWLEDGEMEN'TS

LIST OF TABLES AND FIGURES

EXECUTIVE SUMMARY

INTRODUCTION

DMPA Mechanism of Action

The DMPA Reintroduction Program

iv

The DMPA Monitoring and Follow-up Studies 2

OBJECTIVES OF THE STUDY

METHODOLOGY 6

Sampling Procedure $\quad 6$

Data Collection $\quad 7$

\begin{tabular}{lr} 
Data Processing & 8 \\
\hline
\end{tabular}

$\begin{array}{lr}\text { Method of Analysis } & 8\end{array}$

RESULTS OF THE STUDY:

FINDINGS FROM THE BIVARIATE ANALYSIS

The Socio-Economic and Demographic Profile of Respondents 11 and their Husbands

Profile of Respondents

Profile of Respondents' Husbands $\quad 11$ Marital History 14

$\begin{array}{ll}\text { Reproductive History } & 14\end{array}$

$\begin{array}{ll}\text { Number of Living Children and Pregnancies } & 14\end{array}$

$\begin{array}{ll}\text { Miscarriages and Abortions } & 14\end{array}$

Contraceptive History 、 15

$\begin{array}{lr}\text { First FP Method } & 15\end{array}$

Most Recent/Last Method Before DMPA 16

$\begin{array}{ll}\text { Adoption of DMPA } & 19\end{array}$

Factors Which Influenced Respondent's Decision to Use DMPA 19

Access to the Health Facility 22

Quality of Care related to DMPA use $\quad 22$

Provision of DMPA for the First Time $\quad 24$

R's Rating of the Health Provider 25

Pre-screening Questions Asked Before Giving DMPA 25

$\begin{array}{ll}\text { Counselling and Guidance on DMPA Side Effects } & 28\end{array}$

Respondents' Experience with DMPA 31

Physical Side Effects $\quad 31$

Emotional Changes $\quad 33$

DMPA vs. Other FP Methods $\quad 33$

The Role of the Husband $\quad 35$ 
Husband-Wife Communication about Family Size and FP Practice 36 Husband-Wife Discussions Regarding Family Size $\quad 36$ $\begin{array}{ll}\text { Husband-Wife Discussions Regarding FP } & 38\end{array}$ Opinion on DMPA held by Relatives and Peers $\quad 40$

Discussions on DMPA with Family and Relatives $\quad 40$

Discussions with Peers and Neighbors $\quad 40$

FINDINGS FROM THE MULTIVARIATE ANALYSIS $\quad 42$

SUMMARY, CONCLUSION AND IMPLICATIONS

REFERENCES 


\section{LIST OF FIGURES AND TABLES}

Title

Page

Table 1. Delivery System for Progestin-only Contraceptives 2

Table 2. Geographic Distribution of Sample Health

Facilities and Respondent 7

$\begin{array}{lll}\text { Table 3. } & \text { Profile of Respondents } & 12\end{array}$

Table 4. Profile of Husbands 13

Table 5. Pregnancy and Childbearing 15

$\begin{array}{lll}\text { Table 6. } & \text { Contraceptive History } & 17\end{array}$

Table 7. Factors Which Influenced R's Decision to Use DMPA 19

Table 8. Quality of Care Related to DMPA 22

Table 9. Quality of Carc Related to Pre-screening Questions Asked by Provider 26

Table 10. Quality of Care Related to Provider Counselling and Guidance on Side Effects

Table 11. R's Experience and Management of DMPA Side Effects/Emotional Changes $\quad 32$

Table 12. R's Rating of DMPA 34

Table 13. Husband's Role in R's DMPA Use 35

Table 14. Husband-Wife Communication Regarding
Number of Children

Table 15. Number of Children Wanted and When 37

Table 16. FP Discussions Before and After Marriage 39

Table 17. Opinion of Family Members, Relatives and Peers on DMPA , 41

Table 18. Logit Coefficients and Odds Ratios of Best Model to Predict the Probability of Continuing DMPA 


\section{EXECUTIVE SUMMARY}

In 1994, the Population Council, Manila conducted an OR project entitled the DMPA Monitoring and Follow-up Studies. This activity was undertaken to provide accurate and timely information support to the DMPA Reintroduction Program of the Department of Health. Commonly known as Depo-Provera, DMPA stands for Depo-Medroxy Progesterone Acetate, an extremely effective injectable contraceptive given every three months. This report focuses on the survey component of these studies with the aim of examining comprehensively the influence on DMPA use of factors classified into the following eight major areas: (1) socioeconomic and demographic characteristics; (2) reproductive history; (3) contraceptive history; (4) adoption of DMPA; (5) quality of care related to DMPA; (6) the respondent's experience with DMPA; (7) husband-wife communication regarding family size and family planning practice; and (8) attitudes towards DMPA held by relatives and peers.

Findings in this report are taken from bivariate and multivariate analyses of 812 women who were randomly selected from DMPA acceptors in nine of the ten LGUs covered by the first

phase of the Program. These sample acceptors were surveyed twice: first in February and then again in June-July 1995 to document their DMPA experience and perceptions since their first DMPA injection.

\section{Socioeconomic and Demographic Characteristics, Marital and Reproductive Histories}

There were no significant associations between the socioeconomic, demographic, marital and reproductive history variables and DMPA continuation rates. More than twenty background factors (e.g. age, education and parity of the respondents) were investigated at this point of the analysis. Even so, it may be of use to program managers to know more 
about the characteristics of the DMPA acceptors so as to better understand the type of women who are most likely to select this contraceptive method. These typically were wives who were rural born, high school educated but not currently working, at the peak age of their childbearing years and with three living children. About 10 percent were already receiving DMPA even if they had only one child. This indicates that the stipulation of providing DMPA to women with at least two children has not been fully complied with. Further still, about three percent of drop-outs were found to be currently pregnant as of the first follow-up survey, thereby suggesting that a small number of pregnant women may have been receiving DMPA. Should this be true, it would indicate a need for stricter procedures during prescreening, so as to clearly establish that no pregnancy is present prior to dispensing DMPA. (Overall, about a third of the women interviewed said that they had never been asked about this, again showing some laxity in this regard.)

\section{Contraceptive History}

Of the eight contraceptive history variables considered, only the number of methods used before DMPA and the duration of first method used remained important at the multivariate stage. Women with no previous experience with FP prior to receiving DMPA and those with longer durations for the first method used were significantly more likely to be continuing DMPA users as of the survey dates. It appears as though women with a previous history of shifting away from other FP methods are also most likely to discontinue the use of DMPA. Efforts to lengthen continuation rates by improving the quality of care being offered by service providers is therefore suggested by these results.

\section{Adoption of DMPA}

There were 14 intervening variables which were hypothesized to have influenced R's decision to use DMPA. Only three of these turned out to be important when the bivariate analysis was undertaken. These were, first, the timing of the decision to adopt DMPA; 
second, the intention for using DMPA (whether to delay pregnancy or to stop childbearing altogether); and, third, the time required to reach the health facility. At the multivariate level of analysis, though, none of these factors remained significant. Overall, these factors seemed to have relatively little impact on the decision to continue use of DMPA.

\section{Quality of Care Related to DMPA Use}

The quality of care variables may be seen as falling within four subgroups: (1) provision of DMPA for the first time; (2) R's rating of the health provider; (3) pre-screening questions asked before giving DMPA; and (4) counselling and guidance on DMPA side effects.

Under the first subgroup, only two of the six variables examined emerged significant in differentiating between continuing users (CUs) and drop-outs (DOs). These were the provision of information on side effects prior to giving DMPA and whether or not the client had been told to return for a check-up. When these were examined within the multivariate context only the former variable retained its importance. This shows the role which the provision of balanced information can play in convincing DMPA acceptors to continue using the method even after one or another side effect has been experienced.

Also worth stressing is the finding that more than 40 percent of the respondents related that they had not been given DMPA in accordance to the prescribed schedule which is during the first seven days after the onset of menses, within the first 28 days after a delivery if the woman is not breastfeeding, or within two weeks after an abortion. Again, these figures indicate that the quality of care being given at these health facilities could still be improved.

Four of the six variables falling under the second subgroup were significant at the bivariate level of analysis. These consisted of: (a) friendliness and approachableness of the provider; (b) competence of the provider; (c) the respondent's perception on whether patients are 
treated in a caring and courteous manner in the health facility; and (d) client follow-up since receiving DMPA. However, only the respondent's perception about caring/courteous care consistently retained its significance when included in a series of multivariate models. In general, it was the respondents who felt that patients had been treated in a caring and courteous manner who were most likely to continue using DMPA.

A variety of screening questions about the client's medical history constituted the third subgroup of quality of care factors. Bivariate analysis revealed most of these to be significant predictors of continuing user status. However, only the question on whether R was breastfeeding a baby less than six weeks old persisted as significant during the multivariate analyses. As a general conclusion, though, it does seem that asking screening questions prior to giving DMPA is very important in encouraging continued use of DMPA.

The last subgroup of quality of care variables related to counselling and guidance on DMPA side effects including specific side effects of DMPA. While the provision of information about general side effects associated with DMPA was a very important factor in DMPA continuation, the analysis provided somewhat ambiguous findings regarding the specific side effects which should be highlighted by providers. Counselling on how to handle nausea, dizziness, headaches and weakness stood out as a significant correlate of continued DMPA use, even with the addition of multivariate controls. At the same time, though, the multivariate model also showed that provision of information about possible appetite loss worked against the goal of increasing the probability of continued DMPA use.

\section{Respondents' Experience with DMPA}

The respondents' experiences with DMPA were investigated along four lines: (1) physical side effects; (2) emotional changes; (3) evaluation of DMPA; and (4) the role of the husband. Under the physical side effects subgroup, no significant variations between the 
continuing users (CUs) and the drop-outs (DOs) were observed except on weight gain and appetite loss experiences and on action taken for dealing with side effects. A significantly higher proportion of CUs (48 percent) than DOs (39 percent) experienced weight gain, a side effect which at least does not involve discomfort or fear about some resulting illness. The reverse holds true with the experience of appetite loss. While a significantly higher proportion of DOs did something about their side effects, either by following the provider's advice or by returning to the clinic, the advice given on these occasions (e.g. that the symptoms were "normal" and "nothing to worry about") appeared not to be very helpful in preventing method discontinuation.

Experiences of emotional changes such as easily becoming angry did not emerge as significant predictors of DMPA continuation. (This was true as well for the overall comparison involving the experience of at least one physical side effect.)

The third subgroup pertained to a comparison of DMPA with other methods, the length of time the respondent $(\mathrm{R})$ intended to use DMPA, her willingness to recommend DMPA to relatives and friends, and her reasons for recommending DMPA. All of these variables were found to be significant in the bivariate analysis. However, none of them retained their importance in the multivariate analysis.

Husband's support of his wife's use of DMPA persisted as a highly significant predictor of continued DMPA use (in both the bivariate and multivariate contexts). Hence, innovative strategies for making husbands more supportive should be devised. These could include the production of IEC materials for a male audience and the recruitment of more males for FP outreach activities.

\section{Husband-Wife Communication about Family Size and FP Practice}

Husband's desire for more children, the discussion of family planning in general (both before and after marriage) and talking about using a specific type of family planning method after marriage were all found to be important factors affecting DMPA use within the bivariate 
context. However, they were no longer significantly associated with continuation status once other key variables were controlled for statistically except for husband's desire for more children and discussion of family planning before marriage. The net association with continuation status was positive for husband's desire for more children and negative for discussion of family planning before marriage.

\section{Opinion on DMPA Held by Relatives and Peers}

The opposition to DMPA of either close relatives (mothers, sisters or female relatives) or neighbors and friends was closely associated with the decision to discontinue DMPA use when considered at the bivariate level. Again, however, this correlation was reduced towards statistical nonsignificance within the multivariate context.

\section{Conclusion}

On the whole, DMPA continuation is facilitated by several circumstances. Women who did not exhibit a previous pattern of continued FP method switching were found to be more likely to stay with DMPA. Support from the woman's husband and from her FP provider also played a key role in reducing drop-out rates, as did the provision of detailed information about side effects and the provider's willingness to ask all relevant screening questions. On the other hand, telling acceptors about appetite loss and husband-wife discussion about family planning before marriage inhibited DMPA continuation. By paying greater attention to male outreach activities and to quality of care in FP provision, program managers should be able to increase the adoption and continued use of this important new addition to the Philippine Family Planning Program. 


\section{INTRODUCTION}

For the past few decades the Philippine population scenario has been characterized by uneven and incomplete progress through the demographic transition. Birth rates remain among the highest in Southeast Asia while the use of modern contraceptive methods is still confined to a definite minority of currently married women. High levels of unmet need and method discontinuation continue to plague the country's family planning (FP) program, along with associated problems of method mix, quality of care, and manpower shortages.

One solution to a number of the above-mentioned problems might be to make a wider variety of FP methods available to Filipino couples. Injectable progestin contraceptives represent a particularly attractive option along these lines. These are now being used in over 90 countries with Depo Medroxy Progesterone Acetate (DMPA) being the most preferred choice (Lee et al., 1989; Liskin et $\underline{\text { al., }}$ 1987). In some Asian countries, such as Bangladesh and Thailand, DMPA (commonly known as "Depo-Provera") has been in use for over two decades. In the Philippines, DMPA was first introduced in 1978 in a few pilot areas. It was later withdrawn from the Philippine program although it continued to be distributed in a few private sector clinics.

DMPA's Mechanism of Action. Depo-Provera is an extremely effective contraceptive option, delivered by means of a deep intramuscular injection given every three months. It

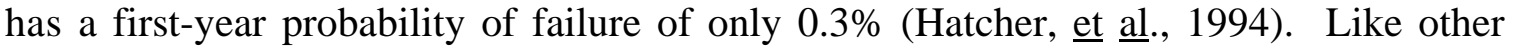
progestin-only contraceptives, it prevents pregnancy by means of several mechanisms particularly via the inhibition of ovulation and the thickening of the cervical mucus thereby making sperm penetration more difficult. A long-term user of DMPA has a two-week "grace period" (longer in many instances) during which she can be late for her next shot but still not be at great risk of becoming pregnant. Table 1 presents the delivery systems for Depo-Provera along with two other progestin-only contraceptives, Norplant and the Progestin-only pill, as adapted from Guilleband (1985). 
Table 1. Delivery Systems for Progestin-only Contraceptives

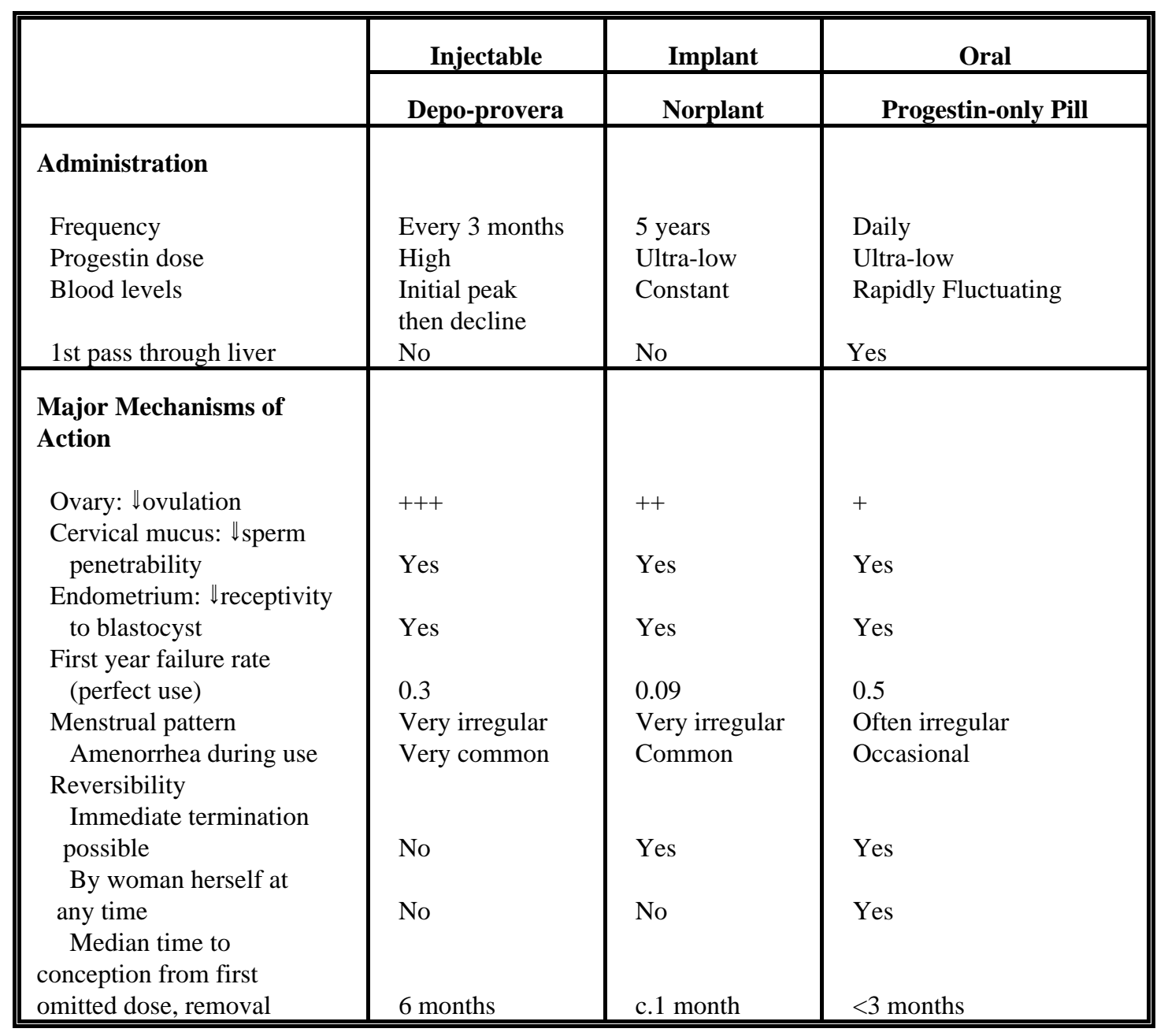

The DMPA Reintroduction Program. After its 1992 approval by the U.S. Food and Drug Administration, the Philippine Family Planning Program (PFPP) reintroduced DMPA in 1994 with a view towards making it available nationwide by early 1996. Ten local government units (LGUs) were chosen as sites for the first phase of the reintroduction program. Phase II called for the expansion of the program to include the remaining provinces and cities within the regions where the Phase I LGUs were located. Phase III would then involve the rest of the country. The program consists of training DMPA service providers and providing free DMPA injections and related services in public sector facilities. 
The DMPA Monitoring and Follow-Up Studies. In late 1994 the Population Council, Manila, in response to a request from members of the DMPA Task Force, undertook an operations research (OR) project entitled the DMPA Monitoring and Follow-Up Studies. This project had two main components: first, the monitoring of DMPA acceptance at the clinic level and, second, a series of follow-up studies. The latter consisted of four components: (1) two surveys of a single panel of respondents, the first conducted in February 1995 and the second in June-July 1995; (2) focus group discussions involving DMPA clients, their husbands and current users of other FP methods; (3) interviews with providers in the study areas; and (4) a service statistics checklist of the health facilities in the survey area. In this report we focus exclusively upon data from the two DMPA surveys.

Objectives of the Follow-Up Studies. While the monitoring approach is useful in quantifying broad trends in the DMPA reintroduction effort, insights into the perspectives of providers, clients and their husbands were also deemed necessary to give a fuller picture of the program. Specifically, it is important to examine the general clinic experience as seen from the eyes of the different actors involved in order to better appreciate the issues surrounding DMPA utilization, including any reasons why clients might decide to discontinue use of this method.

The purpose of the present study is to shed light on several aspects of the DMPA Reintroduction Program in the Philippines, namely:

1. Why do women decide to use DMPA?

2. What side effects, if any, do women usually experience with DMPA and how do they manage these?

3. What makes women decide to continue or discontinue use of DMPA? 
4. How do continuing users of DMPA compare to those who have dropped out from the program?

5. How do clients assess the public sector health delivery system including the quality of care which it provides?

An emphasis on DMPA discontinuation was deemed appropriate from the early stages of the study. Despite its numerous advantages, DMPA users worldwide have generally complained about side effects, particularly those associated with changes in their menstrual bleeding patterns. As a result, relatively few women continue to use DMPA for an extended period of time. It was expected that this problem would be particularly salient in the Philippines, where the side effects issue has typically been the major self-reported cause for terminating FP use (e.g. Palma-Sealza, 1993).

Our comparison between continuing users and drop-outs can be expected to generate several useful programmatic implications. If women with certain background characteristics are found to use the method for a longer period of time, on average, this information might prove useful in IEC campaigns. It will likewise prove of interest to see if certain programbased factors (in particular, the quality of service provided to DMPA acceptors) are themselves associated with continuing use. For example, Jain, Bruce and Kumar (1992) have shown that the quality of follow-up care provided to FP acceptors can have a significant impact upon their willingness to tolerate certain uncomfortable but non-life threatening side effects.

The impact which family and friends may have upon DMPA continuation rates will also be explored in this report. Of particular concern in this instance is the role played by husbands of DMPA acceptors in encouraging their continued use of this FP technique. At least one previous study (Riley, Stewart and Chakraborty, 1994) has found that spousal approval can significantly extend the period of DMPA use. 
The present report is a sequel to two earlier analyses which provided both a univariate analysis (see Patron and Palabrica-Costello, 1995) and a bivariate analysis (see Arenas and Palabrica-Costello, 1995) of data from the first survey round. In this case we supplement these early efforts along two important dimensions: first, by reporting new tabulations based on the second-round data and, secondly, by undertaking a multivariate analysis of factors associated with continuing user status as of the second survey round. 


\section{METHODOLOGY}

Sampling Design. The 10 pilot areas selected for the first phase of the DMPA Reintroduction program were Baguio City, Quezon City, Laguna and Pangasinan in Luzon; Iloilo City and Cebu in the Visayas; and Davao City, Davao del Sur, South Cotabato and Surigao del Sur in Mindanao. Given that Iloilo City did not have at least ten DMPA acceptors per health facility between April and September 1994, it was excluded in the two follow-up studies.

A two-stage sampling design was used within the remaining nine pilot areas. During the first stage, a sample of public health facilities was selected, as were comprised of barangay health stations, rural health units, main health centers, and public hospitals. A total of 812 public health facilities in the nine study areas served as the sampling frame for the random selection of 100 sampling units based on probability proportional to size (number of public health facilities) in each study area. The second stage then consisted of a random selection of 900 sample respondents, again as based on the probability proportional to size procedure (i.e., the total number of DMPA acceptors) in each of the 100 public health facilities. All new acceptors of DMPA during the period April to September 1994 in the primary sampling units provided the sampling frame. Columns 1 and 2 of Table 2 show the geographic distribution of the sample health facilities and the respondents for the OR follow-up study. Only one interview out of the entire sample was not successfully completed at that time, thereby reducing the effective sample size to 899 cases for the first follow-up study.

During the second visit only 812 respondents out of the original 899 were found and successfully interviewed. There were therefore 87 original respondents who could no longer be located in their residence or within the community at this point, either because thay had moved to another community or because they were visiting elsewhere during the second follow-up survey. Column 3 of Table 2 presents the sample respondents for the second follow-up study again by major geographical and pilot area location. 
Table 2. Geographic Distribution of Sample Health Facilities and Respondents

\begin{tabular}{|c|c|c|c|}
\hline LGUs & $\begin{array}{c}\text { Sample } \\
\text { Health } \\
\text { Facilities }\end{array}$ & $\begin{array}{c}\text { Completed } \\
\text { Interviews } \\
\text { (First Survey) }\end{array}$ & $\begin{array}{c}\text { Completed } \\
\text { Interviews } \\
\text { (Second Survey) }\end{array}$ \\
\hline LUZON & & & 26 \\
\hline 1. Baguio City & 3 & 36 & 230 \\
\hline 2. Pangasinan & 30 & 250 & 102 \\
\hline 3. Quezon City & 8 & 122 & 51 \\
\hline 4. Laguna & 6 & 55 & 145 \\
\hline VISAYAS & & & 151 \\
\hline 5. Cebu & 18 & & 28 \\
\hline MINDANAO & 17 & 32 & 113 \\
\hline 6. Davao City & 13 & 106 & 99 \\
\hline 7. Davao Sur & 1 & 19 & 18 \\
\hline 8. South Cotabato & 100 & 899 & 812 \\
\hline 9. Surigao Sur & & & \\
\hline TOTAL & & & \\
\hline
\end{tabular}

Data. The responses of the 812 women interviewed during both of the two follow-up studies provide the data analyzed in this report. One questionnaire was developed and used for each of the respondents in the first follow-up study to obtain information on the following: socioeconomic profile of respondents and their husbands; marital history; reproductive history and plans; contraceptive history; knowledge, motivation, and experience with DMPA; management of side effects; husband-wife communication on FP; and opinions on DMPA held by relatives and peers.

During the second survey round, respondents were classified into four categories: (1) continuing users from the first survey date to June 1995 (the second survey date); (2) 
continuing users as of the first survey but drop-outs as of June 1995; (3) drop-outs as of the first survey who shifted to another method as of June 1995; and (4) drop-outs as of the first survey who had not started using any other method. Separate questionnaires were developed for each of these four groups of respondents. For the first group, the data collected covered contraceptive history including DMPA use, intention to continue or discontinue DMPA, experience with DMPA, management of DMPA experiences, perceptions about service providers, and husband's awareness and attitude towards DMPA. For the second group, the data collected were similar although in this case the reasons for stopping DMPA use were also collected. For the third group, contraceptive use before and after DMPA adoption, reason for stopping DMPA use, comparison of experiences with DMPA and the method(s) used after DMPA, future DMPA use, perception as to service providers, and the husband's awareness and reaction to the wife's decision to stop DMPA use were asked. For the last group, information was collected on reasons for stopping DMPA use, future intentions to use family planning methods, perceptions about service providers, DMPA as a method and husband's awareness of and attitude toward DMPA.

The questionnaires were prepared in English and translated into four dialects: Tagalog, Ilocano, Pangasinense and Cebuano. Field interviews were subcontracted to three local research institutions: the Research Institute for Mindanao Culture (RIMCU), Xavier University; the Social Development Research Center (SDRC), De La Salle University; and the Social Research Office (SRO), Ateneo de Davao University.

Data Processing. The three research institutions also undertook the manual coding of completed interviews. In this regard they used a standard coding manual developed for the study. Machine encoding and processing were carried out by personnel from RIMCU using the software SPSS-PC+.

Method of Analysis. This report examines operational aspects of the 1994 DMPA Reintroduction Program with particular emphasis on clients' perspectives. It concentrates on the acceptance, continuation and perceptions of DMPA acceptors during a period of about 
a year (April 1994 to June 1995). Its major concern is to examine the programmatic factors that are likely to influence DMPA use. Hence, it classifies the 812 DMPA acceptors into two groups: continuing-users (CUs) and drop-outs (DOs). CUs include all those who missed their last injection but who were still within the two-week grace period and who indicated their intention to go back for their injection before this had lapsed. DOs refer to those who failed to get their injection and did not intend to continue using DMPA in February 1995 or June 1995. They are also DOs if they missed their appointment for reinjection and surpassed the two-week grace period even if they intend to resume DMPA use at some later time or were not sure about continuing or stopping their use of DMPA. It should be noted as well that our "drop-out" sample actually includes several cases of women who are still using some type of FP. What they have in common, though, is their decision to discontinue DMPA use as of the survey date.

Sample sizes for the present study consisted of 397 cases (48.9 percent) of CUs along with 415 DOs (51.1 percent). This may be compared to the 613 CUs (68 percent) and 286 DOs (32 percent) analyzed in the two earlier reports (e.g. Arenas and Palabrica-Costello, 1995).

Findings presented in this report are based upon two types of analysis. The first level makes a straightforward comparison between CUs and DOs without controlling for any other factor. Seven major areas are investigated in this case: (1) socio-economic and demographic variables; (2) marital history; (3) reproductive history; (4) contraceptive history; (5) adoption of and experience with DMPA; (6) husband-wife communication; and (7) attitudes towards DMPA held by relatives and peers. Chi-square was used for all statistical tests, with the level of significance being ten percent or lower.

The second level uses a multivariate statistical approach to further distinguish CUs from DOs. The multivariate technique is logistic regression using SAS software program.

This fits the model:

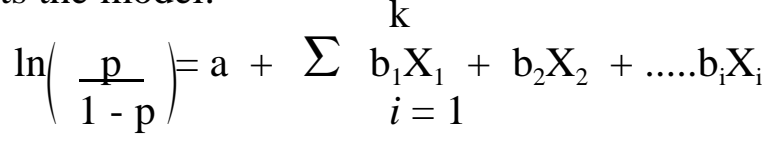

where: $\mathrm{p} \quad=$ probability of continuing the use of DMPA 
$\mathrm{a}, \mathrm{b}_{\mathrm{i}} \quad=$ estimated logistic regression coefficients

$\mathrm{X}_{\mathrm{i}} \quad=$ selected characteristics of the respondents.

This regression analysis yielded the best description of the data and examined the importance of each of the significant factors holding constant the confounding effects of the other major factors affecting DMPA continuation.

Given that all the independent variables are nominal type, one category was selected as the reference category. As pointed out by Younis et $\underline{\text { al }}$. (1993) this approach "estimates a coefficient for each of the remaining categories of the factor that, compared with its standard error, indicates the significance of that category's contribution..., as compared with the reference category." Exponentiating each of the estimated logistic regression coefficients will then yield an odds ratio that expresses the magnitude of DMPA continuation in comparison to the continuation levels found for the reference category. 


\section{RESULTS OF THE STUDY: FINDINGS FROM THE BIVARIATE ANALYSIS}

\section{SOCIO-ECONOMIC AND DEMOGRAPHIC PROFILES OF RESPONDENTS AND THEIR HUSBANDS}

Profile of Respondents. Differences between the CUs and DOs according to selected demographic and socioeconomic characteristics are minimal (Table 3). Both groups exhibit universal marriage and a median age of 29 years. About 70 percent of both groups were born in rural areas. Approximately 8 out of 10 are Roman Catholic. In general, a little more than a quarter of the respondents went to elementary school, half attended at least one year of high school and around 20 percent had some college education. Their median educational attainment is nine years (i.e. third year high school).

Only a minority of the DMPA acceptors (37.0 per cent of CUs and 38.8 percent of DOs) are currently doing anything to earn income. Most (60.1 percent) of these gainfully employed DMPA acceptors are self-employed while about three-fifths (58 percent) are engaged in a white collar occupation. The median monthly income for both groups is one thousand pesos. While a higher proportion of CUs are self-employed (64.6 per cent) and white collar workers (61.2 percent) as compared to the DOs (55.9 and 54.7 percent, respectively), these differences are not statistically significant.

Profile of Respondents' Husbands. As observed with the DMPA acceptors, husbands of the current users do not differ significantly from the husbands of the drop-outs when it comes to their demographic and socioeconomic characteristics (Table 4). The median age for both groups is 32 years old, three years older than their wives. Like most of the sample wives, a majority of husbands were born in a rural area (71.1 percent). Most also are Roman Catholic (82.6 percent) and educated at least as far as first year high school (70.2 percent). Their median level of education is 10 years. Unlike their wives, almost all husbands are currently engaged in income-earning activities. In this case, though, 
the typical job is a blue collar or farming type ( 84.5 percent) while their median monthly earnings are P2,500.

Table 3

Profile of Respondents ${ }^{\mathrm{a}}$

\begin{tabular}{|c|c|c|c|c|}
\hline & Variables & $\begin{array}{l}\text { Continuing } \\
\text { Users } \%\end{array}$ & $\begin{array}{c}\text { Drop-Outs } \\
\%\end{array}$ & Total \\
\hline A. & Married & 100.0 & 100.0 & 100.0 \\
\hline B. & $\begin{array}{l}\text { Age } \\
-17-24 \text { years old } \\
-25-34 \text { years old } \\
-35-45 \text { years old } \\
\text { Median age }\end{array}$ & $\begin{array}{l}21.4 \\
55.7 \\
22.9 \\
29.0\end{array}$ & $\begin{array}{l}23.1 \\
55.9 \\
21.0 \\
29.0 \\
\end{array}$ & $\begin{array}{l}22.3 \\
55.8 \\
21.3 \\
29.0\end{array}$ \\
\hline C. & $\begin{array}{l}\text { Place of birth } \\
\text { - rural } \\
\text { - urban }\end{array}$ & $\begin{array}{l}70.8 \\
29.2\end{array}$ & $\begin{array}{l}69.6 \\
30.4 \\
\end{array}$ & $\begin{array}{l}70.2 \\
29.8 \\
\end{array}$ \\
\hline D. & $\begin{array}{l}\text { Religion } \\
\text { - Roman Catholic } \\
\text { - Other }\end{array}$ & $\begin{array}{l}83.1 \\
16.9 \\
\end{array}$ & $\begin{array}{l}82.2 \\
17.8 \\
\end{array}$ & $\begin{array}{l}82.6 \\
17.4 \\
\end{array}$ \\
\hline E. & $\begin{array}{l}\text { Highest grade completed } \\
\text { - no schooling/elem. 1-6 } \\
\text { - high school } 1 \text { to } 4 \\
\text { - college } 1 \text { to } 4 \text {, post graduate } \\
\text { Median number of years in } \\
\text { school }\end{array}$ & $\begin{array}{c}27.7 \\
52.9 \\
19.4 \\
9.0\end{array}$ & $\begin{array}{c}27.5 \\
51.3 \\
21.2 \\
9.0\end{array}$ & $\begin{array}{c}27.6 \\
52.1 \\
20.3 \\
9.0\end{array}$ \\
\hline F. & $\begin{array}{l}\text { Currently doing anything to } \\
\text { earn income }\end{array}$ & 37.0 & 38.8 & 37.9 \\
\hline G. & $\begin{array}{l}\text { Work Status } \\
\text { - self employed } \\
\text { - employed elsewhere (public, } \\
\text { private) }\end{array}$ & $\begin{array}{r}64.6 \\
35.4 \\
(n=147) \\
\end{array}$ & $\begin{array}{r}55.9 \\
44.1 \\
(n=161) \\
\end{array}$ & $\begin{array}{r}60.1 \\
39.9 \\
(n=308) \\
\end{array}$ \\
\hline H. & $\begin{array}{l}\text { Occupation } \\
\text { - blue collar } \\
\text { - white collar }\end{array}$ & $\begin{array}{r}38.8 \\
61.2 \\
(n=147) \\
\end{array}$ & $\begin{array}{r}45.3 \\
54.7 \\
(n=161) \\
\end{array}$ & $\begin{array}{r}42.2 \\
57.8 \\
(n=308) \\
\end{array}$ \\
\hline I. & $\begin{array}{l}\text { R's monthly income (in pesos) } \\
\text { - } 0 \text { to P999 } \\
\text { - P1,000 to P2,499 } \\
\text { - P2,500 to P21,000 } \\
\text { Median income }\end{array}$ & $\begin{array}{r}45.6 \\
25.2 \\
29.3 \\
P 1,000 \\
(n=147)\end{array}$ & $\begin{array}{r}44.7 \\
21.7 \\
33.5 \\
P 1,000 \\
(n=161)\end{array}$ & $\begin{array}{r}45.1 \\
23.4 \\
31.5 \\
P 1,000 \\
(n=308)\end{array}$ \\
\hline
\end{tabular}

${ }^{a}$ Unless otherwise noted this and all subsequent tables, sample size comes to 812 cases (397 continuing users and 415 drop-outs). Tabulations based on data from the first survey consist of 613 CUs and 286 DOs for a total of 899 cases. 
Table 4

Profile of Husbands

\begin{tabular}{|c|c|c|c|c|}
\hline & Variables & $\begin{array}{l}\text { Husbands of } \\
\text { Continuing } \\
\text { Users } \%\end{array}$ & $\begin{array}{c}\text { Husbands } \\
\text { of Drop-outs } \\
\% \\
\end{array}$ & Total \\
\hline A. & $\begin{array}{l}\text { Age } \\
\text { - } 19 \text { to } 29 \\
\text { - } 30 \text { to } 36 \\
\text { - } 37 \text { to } 66 \\
\text { Median age }\end{array}$ & $\begin{array}{l}34.5 \\
39.0 \\
26.5 \\
32.0 \\
\end{array}$ & $\begin{array}{l}37.8 \\
34.2 \\
28.0 \\
32.0 \\
\end{array}$ & $\begin{array}{l}36.2 \\
36.6 \\
27.2 \\
32.0 \\
\end{array}$ \\
\hline B. & $\begin{array}{l}\text { Place of birth } \\
\text { - rural } \\
\text { - urban } \\
\text { - don't know } \\
\end{array}$ & $\begin{array}{c}69.8 \\
30.0 \\
0.2 \\
\end{array}$ & $\begin{array}{c}72.3 \\
27.5 \\
0.2 \\
\end{array}$ & $\begin{array}{c}71.1 \\
28.7 \\
0.2 \\
\end{array}$ \\
\hline C. & $\begin{array}{l}\text { Religion } \\
\text { - Roman Catholic } \\
\text { - Other }\end{array}$ & $\begin{array}{l}82.3 \\
17.7\end{array}$ & $\begin{array}{l}82.9 \\
17.1\end{array}$ & $\begin{array}{l}82.6 \\
17.4\end{array}$ \\
\hline D. & $\begin{array}{l}\text { Highest grade completed } \\
\text { - no schooling, elem. } 1 \text { to } 6 \\
\text { - high school } 1 \text { to } 4 \\
\text { - college } 1 \text { to } 4 \text {, post graduate } \\
\text { Median number of years in } \\
\text { school }\end{array}$ & $\begin{array}{l}30.7 \\
45.1 \\
24.2 \\
10.0\end{array}$ & $\begin{array}{l}28.9 \\
47.7 \\
23.4 \\
10.0\end{array}$ & $\begin{array}{l}29.8 \\
46.4 \\
23.8 \\
10.0\end{array}$ \\
\hline E. & $\begin{array}{l}\text { Currently working to earn } \\
\text { income }\end{array}$ & 97.2 & 97.8 & 97.5 \\
\hline $\mathrm{F}$. & $\begin{array}{l}\text { Work Status } \\
\text { - self-employed } \\
\text { - employed elsewhere }\end{array}$ & $\begin{array}{r}38.9 \\
61.1 \\
(\mathrm{n}=386) \\
\end{array}$ & $\begin{array}{r}34.7 \\
65.3 \\
(\mathrm{n}=406) \\
\end{array}$ & $\begin{array}{r}36.7 \\
63.3 \\
(\mathrm{n}=792) \\
\end{array}$ \\
\hline G. & $\begin{array}{l}\text { Occupation } \\
\text { - blue collar } \\
\text { - white collar }\end{array}$ & $\begin{array}{r}84.4 \\
15.6 \\
(\mathrm{n}=385) \\
\end{array}$ & $\begin{array}{r}84.7 \\
15.3 \\
(n=404) \\
\end{array}$ & $\begin{array}{r}84.5 \\
15.5 \\
(\mathrm{n}=789)\end{array}$ \\
\hline $\mathrm{F}$. & $\begin{array}{l}\text { Monthly income of R's husband } \\
\text { - } 0 \text { to P1,999 } \\
\text { - P2,000 to P3,499 } \\
\text { - P3,500 to P20,250 } \\
\text { Median income of R's husband }\end{array}$ & $\begin{array}{r}37.2 \\
33.1 \\
29.7 \\
\\
P 2,400.0 \\
(n=384) \\
\end{array}$ & $\begin{array}{r}35.2 \\
35.0 \\
29.8 \\
\\
P 2,600.0 \\
(\mathrm{n}=400) \\
\end{array}$ & $\begin{array}{r}36.2 \\
34.1 \\
29.7 \\
\\
P 2,500.0 \\
(n=784) \\
\end{array}$ \\
\hline
\end{tabular}


Marital History. A large proportion of DMPA acceptors married before age 20 (44.8 percent of CUs and 47.0 percent of DOs). The median age at marriage for both groups is thus only 20 years. With the median current age of DMPA acceptors being 29 years, this means that the typical duration of marriage is about 9 years.

\section{REPRODUCTIVE HISTORY}

Number of Living Children and Pregnancies. There are again no significant differences between CUs and DOs in items of their reproductive history. The median number of living children and of pregnancies for both groups is 3. Although DMPA is recommended for women who already have at least two children, 12.1 percent of the continuing-users and 14.5 percent of the drop-outs have given birth to only one child (Table 5). In fact, when DMPA was first introduced in the Philippines in 1978-1979, a study from Bohol Province showed that as many as 28 percent of acceptors had fewer than 3 children even though it was then stipulated that only women with at least this many should be eligible for an injection (Reynes, 1980). One wonders if this information was conveyed to clients before they received their injections.

Miscarriages/Abortions. There are likewise no substantial variations between the CUs and DOs as to their experience of abortions. A quarter of all respondents from both groups had at least one abortion, whether spontaneous or induced. Three percent of DOs were pregnant as of the first survey date. Two explanations could account for these pregnancies. First, these women might not have realized that they were already expecting a baby at some point after they had their first injection. (If this were true, it would be worth noting that the proper DMPA protocol is to clearly establish that no pregnancy is present. Hence, it would appear that stricter procedures may be needed in this regard.) Second, they may decided to drop out of the program at a relatively early date and then become pregnant soon after that. 
Table 5

Pregnancy and Childbearing

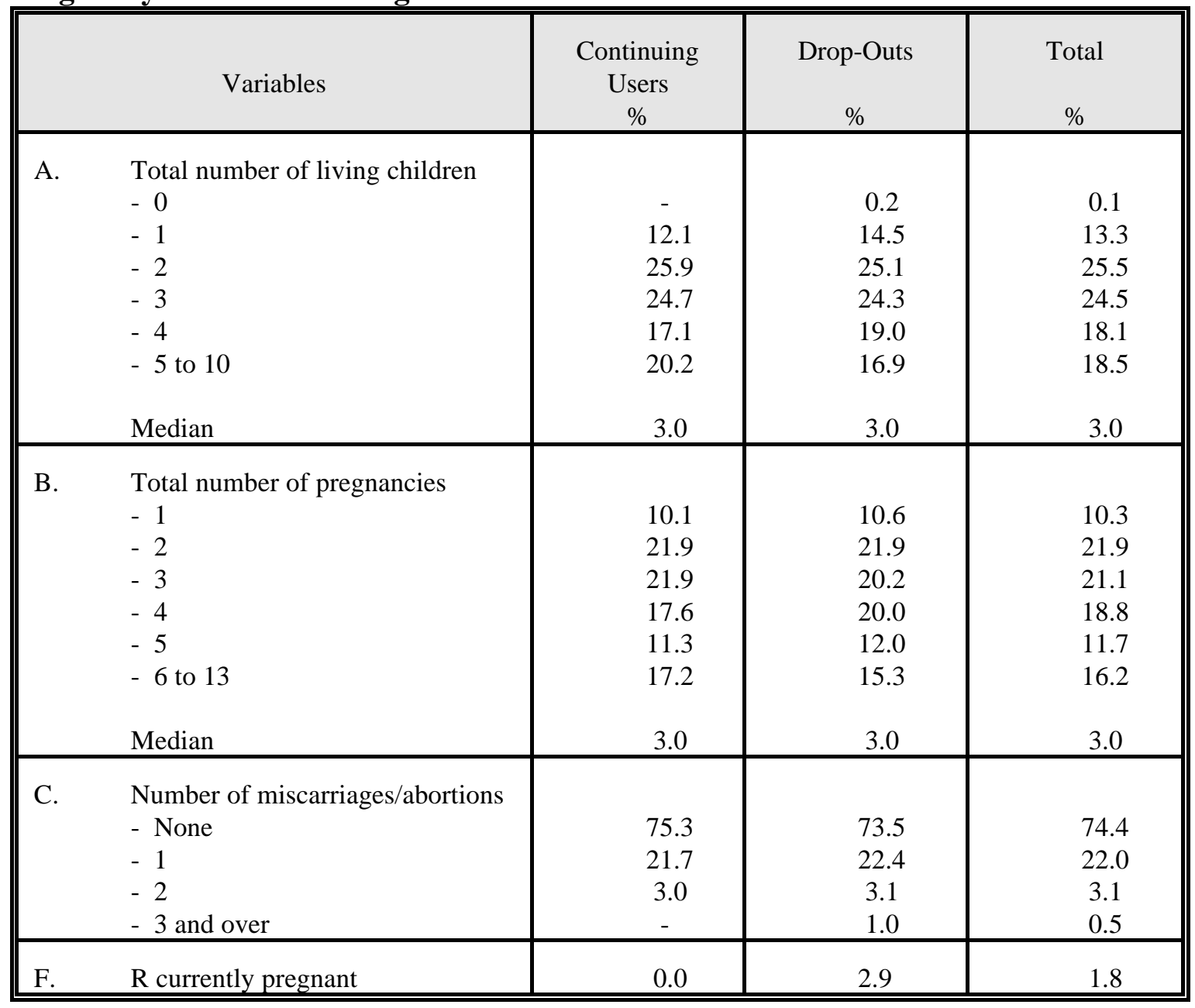

\section{CONTRACEPTIVE HISTORY}

First FP Method. The survey results indicate that a majority of women in both groups (70.3 percent of CUs and 76.2 percent of DOs) had used one or more family planning methods prior to adopting DMPA. Overall, about half of the respondents in both groups had used exactly one such method while slightly more DOs (28.7 percent) than CUs (20.4 percent) had used two or more methods before accepting DMPA. This difference is statistically significant. A large proportion of the previously contracepting respondents (43.2 percent of CUs and 38.8 percent of DOs) reported oral contraceptives/ pills as the first 
family planning method they had used. DMPA was the second most widely used method, followed by withdrawal and the IUD. All other methods accounted for only about 12 percent of the first technique used. These differences (which are shown in Table 6) are also statistically significant.

Thirty-two percent of respondents first used a contraceptive method prior to their first pregnancy or between their first and second pregnancies. Drop-outs tended to become family planning adopters at a somewhat earlier stage of their reproductive history but this difference is not statistically significant.

It is in the duration of the first method used that the two groups significantly differ. In this case longer use is associated with current users rather than with the drop-outs. Overall, more than half of the drop-outs used their method for less than half a year, as compared to none of the current users. In a sense, then, the DOs have a previous history of FP discontinuation. They have experimented with more methods (see above) while also being willing to terminate use of a method more quickly than was true for the CUs.

As expected, among those discontinuing their first method, the main reasons for doing so are side effects/health reasons (49.2 percent of the CUs and 50.4 percent of the DOs) and wanted or accidental pregnancy (about 22 percent in both groups). Noteworthy is the low proportion (only 6 percent overall) who cited disapproval of the husband as their reason for stopping first use of family planning.

Most Recent/Last Method Before DMPA. Contraceptive pills again ranked highest when it came to the most recent method used before DMPA in both follow-up studies. A slight change in rank is observed with the other methods by status of DMPA continuation. Among the CUs, while condom ranked second to pill based on the first survey, it was outranked by withdrawal in the second survey. Among the DOs, while withdrawal ranked second highest in the first survey, it was tied for second by the IUD in the second survey. None of these differences, however, are statistically significant. 
Table 6

\section{Contraceptive History}

\begin{tabular}{|c|c|c|c|c|}
\hline & Variables & $\begin{array}{c}\text { Continuing } \\
\text { Users \% }\end{array}$ & $\begin{array}{c}\text { Drop-Outs } \\
\% \\
\end{array}$ & $\begin{array}{c}\text { Total } \\
\% \\
\end{array}$ \\
\hline A. & $\begin{array}{l}\text { Number of previous methods before DMPA } \\
\text { none } \\
\text { one } \\
\text { more than one } \\
\mathrm{X}^{2}(2 \mathrm{df})=8.5, \mathrm{p} .<.01\end{array}$ & $\begin{array}{l}29.7 \\
49.9 \\
20.4\end{array}$ & $\begin{array}{l}23.9 \\
47.5 \\
28.7\end{array}$ & $\begin{array}{l}26.7 \\
48.6 \\
24.6\end{array}$ \\
\hline B. & $\begin{array}{l}\text { R's first FP method } \\
\text { - DMPA } \\
\text { - pill } \\
\text { - IUD } \\
\text { - condom } \\
\text { - withdrawal } \\
\text { - NFP } \\
\text { - others } \\
X^{2}(9 \mathrm{df})=22.2, \mathrm{p}<.01 \\
\end{array}$ & $\begin{array}{l}29.7 \\
43.3 \\
4.8 \\
6.3 \\
9.8 \\
4.3 \\
1.8\end{array}$ & $\begin{array}{c}23.9 \\
38.8 \\
8.4 \\
5.3 \\
16.6 \\
5.5 \\
1.5\end{array}$ & $\begin{array}{c}26.8 \\
40.9 \\
6.7 \\
5.8 \\
13.3 \\
4.9 \\
1.6\end{array}$ \\
\hline C. & $\begin{array}{l}\text { In between what pregnancy did R first use } \\
\text { FP (including DMPA) } \\
\text { - before 1st pregnancy or between 1st and } \\
\text { 2nd pregnancies } \\
\text { - between 2nd and 3rd pregnancies } \\
\text { - between 3rd and 4th pregnancies } \\
\text { - between higher pregnancies }\end{array}$ & $\begin{array}{l}29.2 \\
24.9 \\
19.4 \\
26.4 \\
\end{array}$ & $\begin{array}{l}33.7 \\
27.7 \\
15.2 \\
23.4 \\
\end{array}$ & $\begin{array}{l}31.5 \\
26.4 \\
17.2 \\
24.9 \\
\end{array}$ \\
\hline D. & $\begin{array}{l}\text { Duration of first method used (in months) } \\
\text { including DMPA first time users } \\
-0-6 \\
-7-9 \\
-10+ \\
\text { Mean } \\
X^{2}(2 d f)=661.2, \text { p. }<.00 \\
\end{array}$ & $\begin{array}{c}- \\
29.2 \\
70.8 \\
10.2\end{array}$ & $\begin{array}{c}63.1 \\
33.5 \\
3.4 \\
6.4\end{array}$ & $\begin{array}{l}32.3 \\
31.4 \\
36.3 \\
7.8\end{array}$ \\
\hline E. & $\begin{array}{l}\text { Reason for discontinuing first FP method } \\
\text { (excluding } 118 \text { CU first users of DMPA) } \\
\text { - to try DMPA } \\
\text { - wanted to get pregnant/accidental } \\
\quad \text { pregnancy } \\
\text { - husband's disapproval } \\
\text { - experienced side effects/health reasons } \\
\text { - fear of side effects } \\
\text { - others }\end{array}$ & $\begin{array}{c}9.0 \\
22.6 \\
4.7 \\
49.2 \\
1.9 \\
12.6\end{array}$ & $\begin{array}{c}8.2 \\
21.7 \\
\\
6.3 \\
50.4 \\
2.0 \\
11.4\end{array}$ & $\begin{array}{c}8.6 \\
22.0 \\
\\
6.0 \\
49.4 \\
2.0 \\
12.0 \\
\end{array}$ \\
\hline
\end{tabular}




\begin{tabular}{|c|c|c|c|c|}
\hline F. & $\begin{array}{l}\text { Most recent/last method before DMPA } \\
\text { (based on second survey) } \\
\text { - pill } \\
\text { - IUD } \\
\text { - condom } \\
\text { - withdrawal } \\
\text { - NFP, rhythm } \\
\text { - others }\end{array}$ & $\begin{array}{c}66.0 \\
8.0 \\
5.0 \\
12.0 \\
5.0 \\
4.0 \\
(\mathrm{n}=265) \\
\end{array}$ & $\begin{array}{c}63.0 \\
11.0 \\
6.0 \\
11.0 \\
7.0 \\
2.0 \\
(\mathrm{n}=290) \\
\end{array}$ & $\begin{array}{c}65.0 \\
10.0 \\
5.0 \\
12.0 \\
6.0 \\
2.0 \\
(\mathrm{n}=555)\end{array}$ \\
\hline G. & $\begin{array}{l}\text { Most recent/last method before DMPA } \\
\text { (based on first survey) } \\
\text { - pill } \\
\text { - IUD } \\
\text { - condom } \\
\text { - withdrawal } \\
\text { - NFP, rhythm } \\
\text { - others }\end{array}$ & $\begin{array}{c}59.9 \\
8.6 \\
12.5 \\
11.5 \\
6.5 \\
1.0 \\
(\mathrm{n}=279) \\
\end{array}$ & $\begin{array}{c}59.5 \\
9.8 \\
10.1 \\
13.6 \\
5.7 \\
1.3 \\
(\mathrm{n}=316) \\
\end{array}$ & $\begin{array}{c}59.7 \\
9.2 \\
11.3 \\
12.6 \\
6.1 \\
1.1 \\
(\mathrm{n}=595) \\
\end{array}$ \\
\hline H. & $\begin{array}{l}\text { Duration of most recent/last method used in } \\
\text { months } \\
-0-6 \\
-7-9 \\
-10+\end{array}$ & $\begin{array}{c}36.5 \\
6.4 \\
57.1\end{array}$ & $\begin{array}{c}39.9 \\
6.2 \\
53.9\end{array}$ & $\begin{array}{c}38.4 \\
6.3 \\
55.3\end{array}$ \\
\hline & Median & $(n=279)$ & $(\mathrm{n}=316)$ & $\begin{array}{r}11.5 \\
(n=595)\end{array}$ \\
\hline I. & $\begin{array}{l}\text { Reason for discontinuing most recent/last } \\
\text { method use } \\
\text { - to try DMPA } \\
\text { - wanted to get pregnant/accidental } \\
\text { pregnancy } \\
\text { - husband's disapproval } \\
\text { - experienced side effects/health reasons } \\
\text { - fear of side effects } \\
\text { - others }\end{array}$ & $\begin{array}{c}9.7 \\
17.2 \\
\\
6.1 \\
47.0 \\
2.5 \\
17.5 \\
(\mathrm{n}=279) \\
\end{array}$ & $\begin{array}{c}13.9 \\
15.8 \\
\\
7.6 \\
46.2 \\
1.3 \\
15.2 \\
(\mathrm{n}=316) \\
\end{array}$ & $\begin{array}{c}11.9 \\
16.5 \\
\\
6.9 \\
46.6 \\
1.8 \\
16.3 \\
(\mathrm{n}=595) \\
\end{array}$ \\
\hline
\end{tabular}

A little below 60 percent of both the CUs and the DOs used their most recent family planning method for ten or more months. Side effects (47.0 percent of CUs and 46.2 percent of DOs) and wanted or accidental pregnancy (17.2 percent of CUs and 15.8 percent of DOs) were the two main reasons for discontinuing the method. 
were the two main reasons for discontinuing the method.

In effect, prior to DMPA acceptance, most of the respondents appear to be "temporary" FP users. This is perhaps not surprising since the use of temporary contraceptives typically does not extend beyond two years. Method switching is therefore common, especially among first-time and adequately informed contraceptive users (Bruce 1990).

\section{ADOPTION OF DMPA}

Factors Which Influenced R's Decision to Use DMPA. For both groups of DMPA acceptors, slightly above 50 percent had only one source of DMPA information. Overall, midwives were the most influential source on DMPA (57.4 of CUs and 59.0 percent of DOs). Friends, relatives, neighbors, barangay health workers, social workers and barangay officials were cited as the next most frequent source of DMPA information (25.4 percent of CUs and 23.1 percent of DOs). A little below 20 percent mentioned doctors, nurses, medical students or media sources such as newspapers, radio, television, DMPA leaflets or mother's classes as their most influential medium for DMPA information. (Please see Table 7.) 
Table 7

Factors Which Influenced R's Decision to Use DMPA

\begin{tabular}{|c|c|c|c|c|}
\hline & Variables & $\begin{array}{l}\text { Continuing } \\
\text { Users } \\
\%\end{array}$ & $\begin{array}{c}\text { Drop-Outs } \\
\% \\
\end{array}$ & $\begin{array}{l}\text { Total } \\
\% \\
\end{array}$ \\
\hline A. & $\begin{array}{l}\text { Number of sources of DMPA information } \\
\text { - only one } \\
\text { - two or more }\end{array}$ & $\begin{array}{l}57.7 \\
42.3 \\
\end{array}$ & $\begin{array}{l}52.3 \\
47.7 \\
\end{array}$ & $45.1^{54.9}$ \\
\hline B. & $\begin{array}{l}\text { R's most influential source of DMPA } \\
\text { information } \\
\text { - doctor, nurse, medical students } \\
\text { - midwife } \\
\text { - friends, relatives, neighbors, BHWs, } \\
\text { social workers, barangay officials } \\
\text { - newspapers, radio, television, DMPA } \\
\text { leaflets, mothers' classes } \\
\end{array}$ & $\begin{array}{r}9.1 \\
57.4 \\
25.4 \\
8.1\end{array}$ & $\begin{array}{r}8.0 \\
59.0 \\
23.1 \\
9.9\end{array}$ & $\begin{array}{r}8.5 \\
58.3 \\
24.3 \\
9.0\end{array}$ \\
\hline C. & $\begin{array}{l}\text { Type of DMPA information R learned } \\
\text { - positive aspects } \\
\text { - negative aspects }\end{array}$ & $\begin{array}{l}73.3 \\
26.7 \\
\end{array}$ & $\begin{array}{l}69.2 \\
30.8 \\
\end{array}$ & $\begin{array}{l}71.2 \\
28.8 \\
\end{array}$ \\
\hline D. & $\begin{array}{l}\text { Nature of information R got from clinic } \\
\text { personnel } \\
\text { - DMPA only } \\
\text { - DMPA plus other methods }\end{array}$ & $\begin{array}{l}63.0 \\
37.0 \\
\end{array}$ & $\begin{array}{l}61.2 \\
38.8 \\
\end{array}$ & $\begin{array}{l}62.1 \\
37.9 \\
\end{array}$ \\
\hline E. & $\begin{array}{l}\text { Other contraceptive methods for which } \\
\text { information was given } \\
\text { - pill } \\
\text { - IUD } \\
\text { - condom } \\
\text { - rhythm/NFP } \\
\text { - ligation }\end{array}$ & $\begin{array}{c}57.4 \\
32.4 \\
5.4 \\
2.1 \\
2.7 \\
(\mathrm{n}=148) \\
\end{array}$ & $\begin{array}{c}55.6 \\
33.1 \\
3.8 \\
5.0 \\
2.5 \\
(\mathrm{n}=160) \\
\end{array}$ & $\begin{array}{c}56.5 \\
32.8 \\
4.5 \\
3.5 \\
2.6 \\
(\mathrm{n}=308) \\
\end{array}$ \\
\hline F. & $\begin{array}{l}\text { Given IEC materials on DMPA and others? } \\
\text { - yes } \\
\text { - no }\end{array}$ & $\begin{array}{l}39.0 \\
61.0\end{array}$ & $\begin{array}{l}40.0 \\
60.0\end{array}$ & $\begin{array}{l}39.5 \\
60.5\end{array}$ \\
\hline G. & $\begin{array}{l}\text { Did clinic personnel tend to promote DMPA } \\
\text { over other methods? } \\
\text { - equally promoted all methods } \\
\text { - promoted DMPA more than other } \\
\text { methods } \\
\text { - tended to promote others over } \\
\quad \text { DMPA/other answers } \\
\end{array}$ & $\begin{array}{l}43.6 \\
45.1 \\
11.3\end{array}$ & $\begin{array}{l}42.9 \\
47.5 \\
9.6\end{array}$ & $\begin{array}{l}43.2 \\
46.3 \\
10.5\end{array}$ \\
\hline H. & $\begin{array}{l}\text { Given extra encouragement to choose over } \\
\text { other methods } \\
\text { - yes } \\
\text { - no }\end{array}$ & $\begin{array}{l}81.9 \\
18.1\end{array}$ & $\begin{array}{l}78.1 \\
21.9\end{array}$ & $\begin{array}{l}79.9 \\
20.1\end{array}$ \\
\hline
\end{tabular}




\begin{tabular}{|c|c|c|c|c|}
\hline I. & $\begin{array}{l}\text { Decision - time to accept DMPA } \\
\text { - immediately } \\
\text { - within two weeks time } \\
\text { - more than two weeks } \\
\mathrm{X}^{2}(\mathrm{df}=2)=5.4, \mathrm{p}<.06\end{array}$ & $\begin{array}{l}69.8 \\
13.4 \\
16.9\end{array}$ & $\begin{array}{l}63.9 \\
19.3 \\
16.9\end{array}$ & $\begin{array}{l}66.7 \\
16.4 \\
16.9\end{array}$ \\
\hline J. & $\begin{array}{l}\text { Husband knowledge about R's use of DMPA } \\
\text { - yes } \\
\text { - no }\end{array}$ & $\begin{array}{r}94.5 \\
5.5 \\
\end{array}$ & $\begin{array}{r}92.0 \\
8.0 \\
\end{array}$ & $\begin{array}{r}93.2 \\
6.8 \\
\end{array}$ \\
\hline $\mathrm{K}$. & $\begin{array}{l}\text { Reasons for choosing DMPA over other } \\
\text { methods } \\
\text { - convenience/effectiveness } \\
\text { - husband's consent } \\
\text { - better alternative } \\
\text { - recommended }\end{array}$ & $\begin{array}{r}66.2 \\
6.3 \\
21.2 \\
6.3\end{array}$ & $\begin{array}{r}68.2 \\
5.5 \\
20.0 \\
6.3\end{array}$ & $\begin{array}{r}67.2 \\
5.9 \\
20.6 \\
6.3\end{array}$ \\
\hline L. & $\begin{array}{l}\text { Intention for using DMPA } \\
\text { - to delay pregnancy } \\
\text { - to stop childbearing } \\
\mathrm{X}^{2}(\mathrm{df}=1)=3.2, \mathrm{p}<.07\end{array}$ & $\begin{array}{l}36.0 \\
64.0\end{array}$ & $\begin{array}{l}42.2 \\
57.8\end{array}$ & $\begin{array}{l}39.2 \\
60.8\end{array}$ \\
\hline
\end{tabular}

The type of information learned appears to be biased towards the positive aspects of DMPA. For the most part (63.0 percent of CUs and 61.2 percent of DOs) it was "DMPA only". Among the minority receiving information on DMPA together with other methods, it was contraceptive pills and IUDs which were most frequently cited as the additional method. Most were only told verbally about DMPA (61.0 percent of CUs and 60.0 percent of DOs) thereby showing that the dissemination of IEC materials on injectables is still not very widespread.

In general, it appears that there are certain gaps to be filled in order to further enable clients to choose the method best suited for their needs. About a fourth of the respondents claimed that the clinic personnel equally promoted all contraceptives. Many, however, thought that DMPA was promoted more than other methods (45.1 percent of CUs and 47.5 percent of DOs). A large majority also claimed that they had been given extra encouragement to choose DMPA over other methods (81.9 of CUs and 78.1 of DOs). It may be that, having been recently trained in DMPA administration, provided with DMPA supplies, and monitored in their use of the same, midwives and other clinic 
personnel were inadvertently led to promote DMPA over other methods.

Nearly all husbands had been informed that their wives were using DMPA. When respondents were asked about their reasons for choosing DMPA, "convenience" or "effectiveness" (66.2 percent of CUs and 68.2 percent of DOs) topped the list followed by "better alternative" (21.2 of CUs and 20.0 of DOs).

There are two statistically significant differentials in Table 6 which bear noting at this point. In general, the drop-outs were a little more hesitant to initially accept DMPA than were the continuing users. About 70 percent of the latter group accepted the injectable "immediately" as compared to only 64 percent of the drop-outs. It is also of some interest to see that the underlying motivation for accepting DMPA may be somewhat weaker among the drop-outs. A bigger proportion of this group (42.2 percent) compared to the CUs (36.0 percent) said that they were using DMPA to delay their next pregnancy. In comparison, the continuing users were significantly more likely to say that they wanted to terminate childbearing altogether.

Access to the Health Facility. Almost all respondents (about 97 percent of both groups) reside within the catchment area of the health facility they are utilizing. Most (60.6 percent) walk to this facility. Again, there was no substantial difference between the two groups in this regard. It is only for the time spent in reaching the health facility that a significant differential may be observed between the CUs and the DOs. In general, the drop-outs were a little more likely than the current users to spend ten or more minutes in reaching the health facility. About 43 percent of the DOs took at least this long, as compared to only 37 percent of the CUs.

\section{QUALITY OF CARE RELATED TO DMPA USE}

Recent years have seen considerable interest in the role which improved quality of care can play towards increasing the number of FP acceptors. According to Anrudh Jain (1992), greater concern about individual clients and their personal reproductive goals can be a cost 
effective approach insofar as this will tend to counteract the widespread problem of FP discontinuation. Some evidence for this idea has already been presented for the Philippines (cf. Palma-Sealza, 1993) but to date there has been no research on its relevance for the special case of DMPA. Data collected during the course of the present study (as presented in Table 8) are therefore of some interest. 
Table 8

Quality of Care Related to DMPA

\begin{tabular}{|c|c|c|c|c|}
\hline & Variables & Continuing-user & Drop-Outs & Total \\
\hline A. & $\begin{array}{l}\text { Who gave first the DMPA injection? } \\
\text { - physician, nurse } \\
\text { - midwife, attendant, others }\end{array}$ & $\begin{array}{r}15.6 \\
84.4 \\
\end{array}$ & $\begin{array}{r}15.9 \\
84.1 \\
\end{array}$ & $\begin{array}{l}15.8 \\
84.2 \\
\end{array}$ \\
\hline B. & $\begin{array}{l}\text { Did R already know the DMPA } \\
\text { provider } \\
\text { - yes } \\
\text { - no } \\
\end{array}$ & $\begin{array}{r}91.4 \\
8.6 \\
\end{array}$ & $\begin{array}{c}90.8 \\
9.2 \\
\end{array}$ & $\begin{array}{r}91.1 \\
8.9 \\
\end{array}$ \\
\hline $\mathrm{C}$. & $\begin{array}{l}\text { Period received first DMPA injection } \\
\text { - before onset of menses } \\
\text { - during first } 7 \text { days, etc. }\end{array}$ & $\begin{array}{r}39.5 \\
60.5 \\
\end{array}$ & $\begin{array}{r}44.8 \\
55.2 \\
\end{array}$ & $\begin{array}{l}42.2 \\
57.8 \\
\end{array}$ \\
\hline D. & $\begin{array}{l}\text { Time when injection was given } \\
\text { - same day } \\
\text { - asked to return }\end{array}$ & $\begin{array}{l}89.7 \\
10.3 \\
\end{array}$ & $\begin{array}{c}90.8 \\
9.2 \\
\end{array}$ & $\begin{array}{r}90.3 \\
9.7 \\
\end{array}$ \\
\hline E. & $\begin{array}{l}\text { R being told to expect side effects } \\
\text { - yes } \\
\text { - no } \\
X^{2}(\mathrm{df}=1)=3.1, \mathrm{p}<.08\end{array}$ & $\begin{array}{l}86.6 \\
13.4\end{array}$ & $\begin{array}{l}82.2 \\
17.8\end{array}$ & $\begin{array}{l}84.4 \\
15.6\end{array}$ \\
\hline F. & $\mathrm{R}$ asked to pay/contribute for DMPA & 73.8 & 69.6 & 71.7 \\
\hline G. & $\begin{array}{l}\text { Amount paid/contributed } \\
\text { - P } 1-5 \\
\text { - P } 6-19 \\
\text { - P } 20 \text { and over }\end{array}$ & $\begin{array}{l}33.0 \\
19.9 \\
47.1 \\
\end{array}$ & $\begin{array}{l}33.5 \\
15.2 \\
51.5 \\
\end{array}$ & $\begin{array}{l}33.1 \\
17.5 \\
49.4 \\
\end{array}$ \\
\hline $\mathrm{H}$. & $\begin{array}{l}\mathrm{R} \text { told to return for check-up } \\
\text { - yes } \\
\text { - no } \\
\mathrm{X}^{2}(\mathrm{df}=1)=5.0, \mathrm{p}<.02\end{array}$ & $\begin{array}{l}62.0 \\
38.0\end{array}$ & $\begin{array}{l}54.2 \\
45.8\end{array}$ & $\begin{array}{l}58.0 \\
42.0\end{array}$ \\
\hline I. & $\begin{array}{l}\text { Number of days in which } \mathrm{R} \text { was told } \\
\text { to return after first injection } \\
\text { - less than } 31 \\
\text { - } 31 \text { or over }\end{array}$ & $\begin{array}{r}29.1 \\
70.9 \\
(\mathrm{n}=179) \\
\end{array}$ & $\begin{array}{r}34.6 \\
65.4 \\
(\mathrm{n}=162) \\
\end{array}$ & $\begin{array}{r}31.7 \\
68.3 \\
(n=341) \\
\end{array}$ \\
\hline $\mathrm{J}$. & $\begin{array}{l}\text { How R thinks of the DMPA provider } \\
\text { - very friendly and approachable } \\
\text { - friendly and approachable } \\
\text { - not so friendly and approachable, } \\
\text { others } \\
\mathrm{X}^{2}(\mathrm{df}=2)=9.3, \mathrm{p}<.01\end{array}$ & $\begin{array}{c}43.8 \\
54.4 \\
1.8\end{array}$ & $\begin{array}{c}33.5 \\
64.1 \\
2.4\end{array}$ & $\begin{array}{c}38.5 \\
59.4 \\
2.1\end{array}$ \\
\hline $\mathrm{K}$. & $\begin{array}{l}\text { How } R \text { rates the DMPA provider's } \\
\text { competence } \\
\text { - very competent } \\
\text { - quite competent } \\
\text { - not so competent } \\
X^{2}(d f=2)=13.1, p<.00\end{array}$ & $\begin{array}{c}44.3 \\
54.7 \\
1.0\end{array}$ & $\begin{array}{c}32.3 \\
65.8 \\
1.9\end{array}$ & $\begin{array}{c}38.2 \\
60.3 \\
1.5\end{array}$ \\
\hline
\end{tabular}




\begin{tabular}{|c|c|c|c|c|}
\hline L. & $\begin{array}{l}\text { R's perception that patients are treated } \\
\text { in a caring and courteous way in the } \\
\text { health center (2nd survey) } \\
\text { - yes } \\
\text { - no } \\
\mathrm{X}^{2}(\mathrm{df}=1)=96.9, \mathrm{p}<.00\end{array}$ & $\begin{array}{c}98.7 \\
1.3\end{array}$ & $\begin{array}{l}78.6 \\
21.4\end{array}$ & $\begin{array}{l}88.4 \\
11.6\end{array}$ \\
\hline M. & $\begin{array}{l}\text { BHW or other health worker came } \\
\text { around to visit R since receiving } \\
\text { DMPA } \\
\text { - yes } \\
\text { - no } \\
\mathrm{X}^{2}(\mathrm{df}=1)=4.7, \mathrm{p}<.03\end{array}$ & $\begin{array}{l}12.8 \\
87.2\end{array}$ & $\begin{array}{c}8.2 \\
91.8\end{array}$ & $\begin{array}{l}10.5 \\
89.5\end{array}$ \\
\hline $\mathrm{N}$ & $\begin{array}{l}\text { Visited or followed-up by a health } \\
\text { personnel during the last two months } \\
\text { - yes } \\
\text { - no }\end{array}$ & $\begin{array}{r}19.9 \\
80.1 \\
\end{array}$ & $\begin{array}{l}21.0 \\
79.0 \\
\end{array}$ & $\begin{array}{l}20.4 \\
79.6 \\
\end{array}$ \\
\hline $\mathrm{O}$. & $\begin{array}{l}\text { Health worker talked about FP during } \\
\text { the visit } \\
\text { - yes } \\
\text { - no }\end{array}$ & $\begin{array}{r}93.7 \\
6.3 \\
(\mathrm{n}=79)\end{array}$ & $\begin{array}{r}94.3 \\
5.7 \\
(\mathrm{n}=87)\end{array}$ & $\begin{array}{r}94.0 \\
6.0 \\
(\mathrm{n}=166)\end{array}$ \\
\hline
\end{tabular}

Provision of DMPA for the First Time. Midwives administered the first DMPA injection to about 84 percent of women in both groups. Large majorities as well were personally acquainted with their DMPA provider prior to adopting DMPA. In neither of these comparisons is a significant differential in evidence.

Providers have been instructed to dispense the first DMPA injection according to the following schedule: during the first 7 days after the beginning of menstruation, within the first 28 days after a delivery if the woman is not breastfeeding or within two weeks of an abortion. Roughly two fifths of the respondents, however, (39.5 percent of CUs and 44.8 percent of DOs) were not given their DMPA in accordance to this schedule. This seems to be related to the fact that almost all respondents (around 90 percent) had their injection on the very same day as their visit to the clinic. While some observers might argue that the timing of the first injection is not a critical matter, this type of omission may be regarded as an indication of a somewhat substandard quality of care now being provided to DMPA acceptors.

More CUs (86.6 percent) than DOs (82.2 percent) were told to expect side effects from their DMPA injection. This variation is statistically significant and may be indicative of the role which the provision of information can play in convincing DMPA acceptors to continue 
using this method even after one or another side effect has been experienced.

Most women in both groups (73.8 percent of the CUs and 69.6 percent of the DOs) were asked to pay or to give some sort of contribution for their injection even though DMPA is supposedly provided for free by the Department of Health. In about half of these cases the amount contributed was P20 or more.

A significantly larger proportion of CUs (62.0 percent) than of DOs (54.2 percent) were told to return for a check-up. Among those told to return, most were asked to do so one month after their first injection (70.9 percent of CUs and 65.4 per cent of DOs).

R's Rating of the Health Provider. Several questions were asked about the respondent's assessment of her DMPA provider. Findings from these comparisons are quite revealing and generally in conformity with the quality of care perspective. DMPA use is thus more likely to be continued if the DMPA provider is perceived as being very friendly and approachable, very competent and seeing to it that her client is subsequently followed-up, whether by her, a barangay health worker, or some other health worker. DMPA use is also more likely to be continued if the respondent feels that patients are treated in a caring and courteous way in the clinic. Stated differently, more CUs (43.8 percent) compared to DOs (33.5 percent) felt that the FP provider was "very" friendly and approachable. Similar results were also obtained with regard to the respondents' willingness to rate their providers as "very" competent (44.3 percent of CUs compared to 32.3 percent of DOs). A much greater proportion of CUs (98.7 percent) than of DOs (78.6 percent) perceived that patients are treated in a caring and courteous way in the clinic. Similarly, more CUs (12.8 percent) were visited by a health worker since their first injection than was true for the DOs (8.2 percent).

This is not to say, however, that high quality care is provided to all, or even most, DMPA acceptors. For example, less than a quarter of such women (whether CUs or DOs) were followed-up by a health personnel and informed about family planning during the two month 
period immediately preceding the second survey.

Screening Questions Asked Before Giving DMPA. Respondents were asked to recall if they were asked a variety of DMPA screening questions (including those pertaining to their health and medical history) prior to being given their first injection (Table 9). In nearly all of these comparisons (10 of 12 cases) a significant differential between the CUs and DOs was obtained. (The two exceptions related to the woman's history of blood clots/heart attack and her contraceptive history.) DMPA acceptors were thus found to be more likely to continue DMPA use if their provider had asked about the following before giving the injection: (1) if the respondent (R) was pregnant or her mense was overdue; (2) if $R$ was breastfeeding a baby less than 6 weeks old; (3) if $\mathrm{R}$ had breast lumps or abnormal discharge from nipples; (4) if R had abnormal, undiagnosed bleeding; (5) if R's eyes had turned yellow, or her urine dark brown in the last six weeks; (6) R's menstrual history; (7) R's current number of children; (8) R's past experience with reproductive tract infections; (9) R's previous experience with anemia, beriberi or malnutrition; and (10) R's past experience with other diseases (e.g. hypertension). These findings again demonstrate that there are definite programmatic benefits to be realized from making the effort to take a personal interest in each client and her own unique needs.

As a follow-up to our earlier contention about already-pregnant women being injected with DMPA, it is noteworthy that nearly a third of all respondents say that they were not asked by the provider if they were pregnant or if their period was late. In the absence of a fullscale pregnancy testing program, it seems that the very least that could be done would be to insist that these sorts of questions be posed to the proposed acceptors. 
Table 9

Quality of Care Related to Screening Questions Asked by Provider

\begin{tabular}{|c|c|c|c|c|}
\hline & Variables & $\begin{array}{c}\text { Continuing } \\
\text { Users } \\
\%\end{array}$ & $\begin{array}{c}\text { Drop-Outs } \\
\%\end{array}$ & $\begin{array}{c}\text { Total } \\
\% \\
\end{array}$ \\
\hline A. & $\begin{array}{l}\text { Asked if } \mathrm{R} \text { was pregnant or her } \\
\text { mense was overdue } \\
\text { - yes } \\
\text { - no } \\
\mathrm{X}^{2}(\mathrm{df}=1)=7.4, \mathrm{p}<.01 \\
\end{array}$ & $\begin{array}{l}72.0 \\
28.0\end{array}$ & $\begin{array}{l}63.1 \\
36.9\end{array}$ & $\begin{array}{l}67.5 \\
32.5\end{array}$ \\
\hline B. & $\begin{array}{l}\text { Asked if } \mathrm{R} \text { was breastfeeding a } \\
\text { baby less than } 6 \text { weeks old } \\
\text { - yes } \\
\text { - no } \\
\mathrm{X}^{2}(\mathrm{df}=1)=5.2, \mathrm{p}<.02\end{array}$ & $\begin{array}{l}67.3 \\
32.7\end{array}$ & $\begin{array}{l}59.5 \\
40.5\end{array}$ & $\begin{array}{l}63.3 \\
36.7\end{array}$ \\
\hline C. & $\begin{array}{l}\text { Asked if } \mathrm{R} \text { had blood clots in her } \\
\text { legs or had had a heart attack } \\
\text { - yes } \\
\text { - no }\end{array}$ & $\begin{array}{r}71.8 \\
28.2 \\
\end{array}$ & $\begin{array}{l}66.7 \\
33.3 \\
\end{array}$ & $\begin{array}{l}69.2 \\
30.8 \\
\end{array}$ \\
\hline D. & $\begin{array}{l}\text { Asked/examined if } \mathrm{R} \text { had breast } \\
\text { lumps or abnormal discharge from } \\
\text { nipples } \\
\text { - yes } \\
\text { - no } \\
\mathrm{X}^{2}(\mathrm{df}=1)=4.4, \mathrm{p}<.04\end{array}$ & $\begin{array}{l}75.1 \\
24.9\end{array}$ & $\begin{array}{l}68.4 \\
31.6\end{array}$ & $\begin{array}{l}71.7 \\
28.3\end{array}$ \\
\hline E. & $\begin{array}{l}\text { Asked if } \mathrm{R} \text { had abnormal, } \\
\text { undiagnosed bleeding } \\
\text { - yes } \\
\text { - no } \\
\mathrm{X}^{2}(\mathrm{df}=1)=5.1, \mathrm{p}<.02\end{array}$ & $\begin{array}{l}63.2 \\
36.8\end{array}$ & $\begin{array}{l}55.4 \\
44.6\end{array}$ & $\begin{array}{l}59.2 \\
40.8\end{array}$ \\
\hline $\mathrm{F}$. & $\begin{array}{l}\text { Asked if R's eyes had turned } \\
\text { yellow, or her urine dark brown in } \\
\text { the last } 6 \text { weeks } \\
\text { - yes } \\
\text { - no } \\
\mathrm{X}^{2}(\mathrm{df}=1)=5.0, \mathrm{p}<.03\end{array}$ & $\begin{array}{l}57.4 \\
42.6\end{array}$ & $\begin{array}{l}49.6 \\
50.4\end{array}$ & $\begin{array}{l}53.4 \\
46.6\end{array}$ \\
\hline G. & $\begin{array}{l}\text { Asked R about her menstrual } \\
\text { history } \\
\text { - yes } \\
\text { - no } \\
\mathrm{X}^{2}(\mathrm{df}=1)=8.0, \mathrm{p}<.00 \\
\end{array}$ & $\begin{array}{l}82.6 \\
17.4\end{array}$ & $\begin{array}{l}74.5 \\
25.5\end{array}$ & $\begin{array}{l}78.4 \\
21.4\end{array}$ \\
\hline H. & $\begin{array}{l}\text { Asked } R \text { about her current number } \\
\text { of children } \\
\text { - yes } \\
\text { - no } \\
X^{2}(\mathrm{df}=1)=8.6, \mathrm{p}<.00\end{array}$ & $\begin{array}{l}82.9 \\
17.1\end{array}$ & $\begin{array}{l}74.5 \\
25.5\end{array}$ & $\begin{array}{l}78.6 \\
21.4\end{array}$ \\
\hline
\end{tabular}




\begin{tabular}{|c|c|c|c|c|}
\hline I. & $\begin{array}{l}\text { Asked } \mathrm{R} \text { about her previous } \\
\text { experience with reproductive tract } \\
\text { infections } \\
\text { - yes } \\
\text { - no } \\
\mathrm{X}^{2}(\mathrm{df}=1)=11.2, \mathrm{p}<.00\end{array}$ & $\begin{array}{l}58.9 \\
41.1\end{array}$ & $\begin{array}{l}47.2 \\
52.8\end{array}$ & $\begin{array}{l}53.0 \\
47.0\end{array}$ \\
\hline J. & $\begin{array}{l}\text { Asked } \mathrm{R} \text { about her previous } \\
\text { experience with } \\
\text { anemia/beriberi/malnutrition } \\
\text { - yes } \\
\text { - no } \\
\mathrm{X}^{2}(\mathrm{df}=1)=6.0, \mathrm{p}<.01\end{array}$ & $\begin{array}{l}58.2 \\
41.8\end{array}$ & $\begin{array}{l}49.6 \\
50.4\end{array}$ & $\begin{array}{l}53.8 \\
46.2\end{array}$ \\
\hline $\mathrm{K}$. & $\begin{array}{l}\text { Asked } R \text { about her previous } \\
\text { experience with other diseases } \\
\text { (heart, hypertension, etc.) } \\
\text { - yes } \\
\text { - no } \\
\mathrm{X}^{2}(\mathrm{df}=1)=3.1, \mathrm{p}<.08 \\
\end{array}$ & $\begin{array}{l}68.3 \\
31.7\end{array}$ & $\begin{array}{l}62.4 \\
37.6\end{array}$ & $\begin{array}{l}65.3 \\
34.7\end{array}$ \\
\hline L. & $\begin{array}{l}\text { Asked } \mathrm{R} \text { about her previous } \\
\text { contraceptive history } \\
\text { - yes } \\
\text { - no }\end{array}$ & $\begin{array}{l}64.2 \\
35.8\end{array}$ & $\begin{array}{l}59.5 \\
40.5\end{array}$ & $\begin{array}{l}61.8 \\
38.2\end{array}$ \\
\hline
\end{tabular}

Counselling and Guidance on DMPA Side Effects. Informing clients of possible side effects and guiding them on the manner in which these can be handled are expected to influence the continuation of DMPA use. Data found in Table 10 (as were gathered during the two surveys) show that informing clients about possible side effects of DMPA is indeed significantly associated with the continued use of this method. Among the CUs, 86.6 percent from the first survey and 90.7 percent from the second survey affirmed that this had been true in their case as compared to 82.2 percent and 63.6 percent, respectively, of the DOs. However, when it comes to specific side effects, a negligible proportion of both CUs and DOs (12 percent or below for each case) were told about weight gain, appetite loss or heavy bleeding. Two kinds of side effects (nausea/ dizziness/headaches/weakness and spotting) appear to have been told by DMPA providers to almost half of their clients. No substantial differences were observed between CUs and DOs in this regard.

A third or less (33.3 percent or less for all subgroups) of the respondents were not advised on how to handle these side effects. There are no substantial differences observed between CUs and DOs on this except for the handling of nausea and its related conditions, in which 
case a significantly larger proportion of DOs (16.4 percent) were not given any instruction as compared to only 5.7 percent of CUs. 
Table 10

Quality of Care Related to Provider Counselling and Guidance on Side Effects

\begin{tabular}{|c|c|c|c|c|}
\hline & Variables & \multirow{2}{*}{$\begin{array}{l}\text { Continuing } \\
\text { Users \% } \\
\\
10.2 \\
89.8 \\
(n=343)\end{array}$} & \multirow{2}{*}{$\begin{array}{c}\text { Drop-Outs } \\
\% \\
\\
11.1 \\
88.9 \\
(\mathrm{n}=342)\end{array}$} & \multirow{2}{*}{$\begin{array}{c}\begin{array}{c}\text { Total } \\
\%\end{array} \\
\\
\\
10.7 \\
89.3 \\
(\mathrm{n}=685)\end{array}$} \\
\hline A. & $\begin{array}{l}\text { R being told about weight gain } \\
\text { - yes } \\
\text { - no }\end{array}$ & & & \\
\hline B. & $\begin{array}{l}R \text { being told about appetite loss } \\
\text { - yes } \\
\text { - no } \\
X^{2}(\mathrm{df}=1)=3.2 \mathrm{p}<.08\end{array}$ & $\begin{array}{r}0.9 \\
99.1 \\
(\mathrm{n}=343) \\
\end{array}$ & $\begin{array}{r}2.6 \\
97.4 \\
(n=342) \\
\end{array}$ & $\begin{array}{r}1.8 \\
98.2 \\
(\mathrm{n}=685) \\
\end{array}$ \\
\hline C. & $\begin{array}{l}\mathrm{R} \text { being told about nausea, dizziness, } \\
\text { headaches, weakness } \\
\text { - yes } \\
\text { - no }\end{array}$ & $\begin{array}{r}51.0 \\
49.0 \\
(\mathrm{n}=343) \\
\end{array}$ & $\begin{array}{r}48.5 \\
51.5 \\
(n=342)\end{array}$ & $\begin{array}{r}49.8 \\
50.2 \\
(\mathrm{n}=685)\end{array}$ \\
\hline D. & $\begin{array}{l}\text { R being told about heavy bleeding } \\
\text { - yes } \\
\text { - no }\end{array}$ & $\begin{array}{r}12.2 \\
87.8 \\
(\mathrm{n}=343)\end{array}$ & $\begin{array}{r}11.1 \\
88.9 \\
(\mathrm{n}=342)\end{array}$ & $\begin{array}{r}11.7 \\
88.3 \\
(\mathrm{n}=685) \\
\end{array}$ \\
\hline E. & $\begin{array}{l}\mathrm{R} \text { being told that bleeding would } \\
\text { stop or be reduced (amenorrhea) } \\
\text { - yes } \\
\text { - no }\end{array}$ & $\begin{array}{r}48.7 \\
51.3 \\
(n=343)\end{array}$ & $\begin{array}{r}48.0 \\
52.0 \\
(n=342)\end{array}$ & $\begin{array}{r}48.3 \\
51.7 \\
(\mathrm{n}=685)\end{array}$ \\
\hline F. & $\begin{array}{l}\text { R being told about spotting } \\
\text { - yes } \\
\text { - no }\end{array}$ & $\begin{array}{r}55.4 \\
44.6 \\
(\mathrm{n}=343) \\
\end{array}$ & $\begin{array}{r}51.8 \\
48.2 \\
(n=342) \\
\end{array}$ & $\begin{array}{r}53.6 \\
46.4 \\
(n=685)\end{array}$ \\
\hline G. & $\begin{array}{l}\mathrm{R} \text { advised on how to handle weight } \\
\text { gain } \\
\text { - yes } \\
\text { - no }\end{array}$ & $\begin{array}{r}77.1 \\
22.9 \\
(n=35) \\
\end{array}$ & $\begin{array}{r}84.2 \\
15.8 \\
(n=38)\end{array}$ & $\begin{array}{r}80.8 \\
19.2 \\
(\mathrm{n}=73)\end{array}$ \\
\hline H. & $\begin{array}{l}\text { R advised on how to handle appetite } \\
\text { loss } \\
\text { - yes } \\
\text { - no }\end{array}$ & $\begin{array}{r}66.7 \\
33.3 \\
(n=3)\end{array}$ & $\begin{array}{r}75.0 \\
25.0 \\
(n=8)\end{array}$ & $\begin{array}{r}72.7 \\
27.3 \\
(\mathrm{n}=11)\end{array}$ \\
\hline
\end{tabular}




\begin{tabular}{|c|c|c|c|c|}
\hline I. & $\begin{array}{l}\mathrm{R} \text { advised on how to handle nausea, } \\
\text { dizziness, headaches, weakness } \\
\text { - yes } \\
\text { - no } \\
\mathrm{X}^{2}(\mathrm{df}=2)=11.6, \mathrm{p}<.00\end{array}$ & $\begin{array}{r}94.3 \\
5.7 \\
(\mathrm{n}=176) \\
\end{array}$ & $\begin{array}{r}83.6 \\
16.4 \\
(\mathrm{n}=165) \\
\end{array}$ & $\begin{array}{r}88.9 \\
10.9 \\
(\mathrm{n}=341)\end{array}$ \\
\hline J. & $\begin{array}{l}\mathrm{R} \text { advised on how to handle heavy } \\
\text { bleeding } \\
\text { - yes } \\
\text { - no }\end{array}$ & $\begin{array}{r}92.7 \\
7.3 \\
(\mathrm{n}=41) \\
\end{array}$ & $\begin{array}{r}84.2 \\
15.8 \\
(\mathrm{n}=38) \\
\end{array}$ & $\begin{array}{r}88.6 \\
11.4 \\
(\mathrm{n}=79) \\
\end{array}$ \\
\hline $\mathrm{K}$. & $\begin{array}{l}\mathrm{R} \text { advised on how to handle } \\
\text { cessation or reduction of bleeding } \\
\text { (amenorrhea) } \\
\text { - yes } \\
\text { - no }\end{array}$ & $\begin{array}{r}90.4 \\
9.6 \\
(\mathrm{n}=166) \\
\end{array}$ & $\begin{array}{r}89.1 \\
10.9 \\
(n=165) \\
\end{array}$ & $\begin{array}{r}89.7 \\
10.3 \\
(\mathrm{n}=331) \\
\end{array}$ \\
\hline L. & $\begin{array}{l}\mathrm{R} \text { advised on how to handle spotting } \\
\text { - yes } \\
\text { - no }\end{array}$ & $\begin{array}{r}86.8 \\
13.2 \\
(\mathrm{n}=190) \\
\end{array}$ & $\begin{array}{r}85.8 \\
14.2 \\
(\mathrm{n}=176) \\
\end{array}$ & $\begin{array}{r}86.1 \\
13.7 \\
(\mathrm{n}=366) \\
\end{array}$ \\
\hline M. & $\begin{array}{l}\mathrm{R} \text { informed about possible side } \\
\text { effects associated with DMPA (1st } \\
\text { survey) } \\
\text { - yes } \\
\text { - no } \\
\mathrm{X}^{2}(\mathrm{df}=1)=3.1, \mathrm{p}<.08 \\
\end{array}$ & $\begin{array}{l}86.6 \\
13.4\end{array}$ & $\begin{array}{l}82.2 \\
17.8\end{array}$ & $\begin{array}{l}84.4 \\
15.6\end{array}$ \\
\hline $\mathrm{N}$. & $\begin{array}{l}\mathrm{R} \text { informed about possible side } \\
\text { effects associated with DMPA (for } \\
\text { CUs and DO-non-shifters) and other } \\
\text { methods (for DO-shifters) } \\
\text { - yes } \\
\text { - no } \\
\mathrm{X}^{2}(\mathrm{df}=1)=88.6, \mathrm{p}<.00\end{array}$ & $\begin{array}{c}90.7 \\
9.3\end{array}$ & $\begin{array}{l}63.6 \\
36.4\end{array}$ & $\begin{array}{l}76.8 \\
23.2\end{array}$ \\
\hline
\end{tabular}




\section{RESPONDENTS' EXPERIENCE WITH DMPA}

Physical Side Effects. Although we would have expected a higher proportion of drop-outs to report that they experienced side effects, this did not turn out to be true. Instead, a large proportion of both groups (89.2 percent of continuing users and 89.9 percent of drop-outs) said that they had undergone this experience (Table 11). It might be, therefore, that the DOs were experiencing the more severe kinds of side effects or that they were less able to cope with whatever changes they had felt. At this point, therefore, it would perhaps be more meaningful to compare the kinds of side effects described by the two groups. It is interesting to note in this regard that a significantly higher proportion of CUs (47.5 percent) than of DOs (38.5 percent) experienced weight gain, a side effect which at least does not involve discomfort or fear about some resulting illness. In comparison, more of the DOs (8.3 percent) than of the CUs ( 4.0 percent) reported appetite loss. There are, however, no significant variations between the two groups when it comes to the other side effects although the DOs rank a little higher on "weakness" and "heavy bleeding".

Also noteworthy is the fact that a significantly higher proportion of DOs did something about their side effects, either by following the provider's advice or by returning to the clinic. It thus seems that the advice given on these occasions (e.g. that the symptoms were "normal" and "nothing to worry about") was not very helpful in preventing method discontinuation. Even so, about three-fourths of those who returned to the clinic (whether they were a $\mathrm{CU}$ or a DO) said that they were satisfied with the results of the advice/medication provided them. 
Table 11

R's Experience and Management of DMPA Side Effects/Emotional Changes

\begin{tabular}{|c|c|c|c|c|}
\hline \multicolumn{2}{|r|}{ Variables } & $\begin{array}{l}\text { Continuing } \\
\text { Users } \\
\%\end{array}$ & $\begin{array}{c}\text { Drop-Outs } \\
\%\end{array}$ & $\begin{array}{c}\text { Total } \\
\%\end{array}$ \\
\hline A. & $\begin{array}{l}\text { R experienced physical side } \\
\text { effects }\end{array}$ & 89.2 & 89.9 & 89.5 \\
\hline B. & $\begin{array}{l}\text { Kinds of side effects experienced } \\
\text { (multiple responses) } \\
\text { - weight gain } \\
\quad X^{2}(\mathrm{df}=1)=6.0, \mathrm{p}<.01 \\
\text { - } \text { appetite loss } \\
\quad \mathrm{X}^{2}(\mathrm{df}=1)=6.0, \mathrm{p}<.01 \\
\text { - weakness }\end{array}$ & $\begin{array}{l}47.5 \\
4.0 \\
8.5\end{array}$ & $\begin{array}{l}38.5 \\
8.3 \\
104\end{array}$ & $\begin{array}{l}42.9 \\
6.2 \\
0.5\end{array}$ \\
\hline & - nausea/dizziness/headache & 53.7 & 50.8 & 52.2 \\
\hline & - heavy bleeding & 7.3 & 9.6 & 8.5 \\
\hline & - less than usual bleeding & 14.1 & 14.4 & 14.3 \\
\hline & - non-bleeding/ amenorrhea & 22.9 & 23.3 & 23.1 \\
\hline & - spotting & $\begin{array}{r}43.5 \\
(n=354)\end{array}$ & $\begin{array}{r}41.7 \\
(n=374)\end{array}$ & $\begin{array}{r}42.6 \\
(n=728)\end{array}$ \\
\hline C. & $\begin{array}{l}\text { Action taken on side effects } \\
\text { experienced } \\
\text { - none } \\
\text { - followed provider's advice, } \\
\text { returned to clinic, others } \\
\mathrm{X}^{2}(\mathrm{df}=1)=5.8, \mathrm{p}<.02\end{array}$ & $\begin{array}{r}74.9 \\
25.1 \\
(n=354)\end{array}$ & $\begin{array}{r}66.8 \\
33.2 \\
(n=374)\end{array}$ & $\begin{array}{r}70.7 \\
29.3 \\
(n=728)\end{array}$ \\
\hline D. & $\begin{array}{l}\text { Type of advice given } \\
\text { - normal, nothing to worry } \\
\text { - given some medication }\end{array}$ & $\begin{array}{r}52.5 \\
47.5 \\
(\mathrm{n}=61) \\
\end{array}$ & $\begin{array}{r}64.9 \\
35.1 \\
(\mathrm{n}=94)\end{array}$ & $\begin{array}{r}60.0 \\
40.0 \\
(n=155)\end{array}$ \\
\hline E. & $\begin{array}{l}\text { Satisfied with results of } \\
\text { advice/medication }\end{array}$ & $\begin{array}{r}75.0 \\
(n=61) \\
\end{array}$ & $\begin{array}{r}78.9 \\
(\mathrm{n}=94)\end{array}$ & $\begin{array}{r}77.4 \\
(n=155) \\
\end{array}$ \\
\hline F. & $\mathrm{R}$ experienced emotional changes & 43.1 & 48.0 & 45.6 \\
\hline
\end{tabular}


Emotional Changes. Interestingly, about 45 percent of DMPA acceptors (CUs or DOs) experienced emotional changes. Most of these respondents said that they easily became angry.

DMPA vs. Other FP Methods. Previous users of FP were asked to compare their past method with DMPA (Table 12). Results show that 76.5 percent of CUs compared to 62.1 percent of DOs were more satisfied with DMPA; the reverse holds true with the DOs finding the other methods as being more satisfying. These differentials are statistically significant at the .001 level. Among those who were more satisfied with DMPA, the typical reason given for this is that it is "more convenient" as well as being relatively free from side effects. For the CUs, a total of 76.2 percent gave this response as compared to 61.2 percent of DOs. In comparison, it was the DOs who were most likely (26.6 percent vs. 16.4 percent) to complain that DMPA had "more side effects" than all other methods they had tried. These differences are again statistically significant.

CUs were shown to be significantly more likely to intend on continuing DMPA use than the DOs. They are also more willing to recommend DMPA to relatives and friends. The usual reasons given for this favorable reaction on their part were the method's "convenience" and its lack of side effects. 
Table 12

R's Rating of DMPA

\begin{tabular}{|c|c|c|c|c|}
\hline & Variables & $\begin{array}{c}\text { Continuing } \\
\text { Users } \\
\%\end{array}$ & $\begin{array}{c}\text { Drop-Outs } \\
\%\end{array}$ & $\begin{array}{c}\text { Total } \\
\%\end{array}$ \\
\hline A. & $\begin{array}{l}\text { R's rating of DMPA compared to } \\
\text { other methods } \\
\text { - more satisfied with DMPA } \\
\text { - more satisfied with other methods } \\
\text { - others } \\
X^{2}(2 d f)=15.53, p<.00\end{array}$ & $\begin{array}{c}76.5 \\
16.1 \\
7.4\end{array}$ & $\begin{array}{l}62.1 \\
26.6 \\
11.3\end{array}$ & $\begin{array}{c}68.9 \\
21.6 \\
9.5\end{array}$ \\
\hline B. & $\begin{array}{l}\text { Reason for R's feelings in reference to } \\
\text { DMPA vis a vis other methods } \\
\text { - DMPA - more convenient and no } \\
\text { side effects } \\
\text { - other methods - more side effects } \\
\text { with DMPA compared with } \\
\text { other methods } \\
\text { - others - side effects with DMPA } \\
\text { and other methods } \\
\mathrm{X}^{2}(\mathrm{df}=2)=16.5, \mathrm{p}<.00\end{array}$ & $\begin{array}{r}76.2 \\
16.4 \\
7.4 \\
(n=298)\end{array}$ & $\begin{array}{r}61.2 \\
26.6 \\
12.2 \\
(n=335)\end{array}$ & $\begin{array}{r}68.2 \\
21.8 \\
10.0 \\
(\mathrm{n}=633)\end{array}$ \\
\hline C. & $\begin{array}{l}\text { Length of time } \mathrm{R} \text { intends to use } \\
\text { DMPA in months } \\
\text { - less than } 12 \\
\text { - } 12 \text { to } 180 \\
\text { - no exact answer } \\
\mathrm{X}^{2}(2 \mathrm{df})=50.7, \mathrm{p}<.00 \\
\end{array}$ & $\begin{array}{l}19.6 \\
32.0 \\
48.4\end{array}$ & $\begin{array}{l}42.4 \\
25.1 \\
32.5\end{array}$ & $\begin{array}{l}31.3 \\
28.4 \\
40.3\end{array}$ \\
\hline D. & $\begin{array}{l}\text { Willing to recommend DMPA to } \\
\text { relatives and friends } \\
\text { - yes } \\
\text { - no } \\
\mathrm{X}^{2}(1 \mathrm{df})=14.3, \mathrm{p}<.00\end{array}$ & $\begin{array}{l}86.6 \\
13.4\end{array}$ & $\begin{array}{l}76.4 \\
23.6\end{array}$ & $\begin{array}{l}81.4 \\
18.6\end{array}$ \\
\hline E. & $\begin{array}{l}\text { Reasons among those responding: } \\
\text { - yes, mostly convenience; no side } \\
\text { effects } \\
\text { - no, mostly fear not to be blamed; } \\
\text { side effects } \\
\mathrm{X}^{2}(1 \mathrm{df})=14.9, \mathrm{p}<.00\end{array}$ & $\begin{array}{l}86.6 \\
13.4\end{array}$ & $\begin{array}{l}76.1 \\
23.9\end{array}$ & $\begin{array}{l}81.3 \\
18.7\end{array}$ \\
\hline
\end{tabular}

The Role of the Husband. Table 13 gives an indication as to whose initiative led respondents to use DMPA. The majority stated that it was the couples' joint decision (71.0 percent for the CUs and 68.7 precent among the DOs). A smaller number of respondents 
said it was largely their own decision (27.7 percent of CUs and 29.4 percent of DOs). Only a very small percentage (2.2 percent) had concealed their DMPA use from their spouse. When asked to describe their husbands' feelings with regard to their receiving DMPA, a significantly larger percentage of CUs than DOs (85.1 percent vs. 72.5 percent) stated during the first survey that their husband was supportive of this method. Comparable statistics as of the second survey were 91.4 percent supportive among the CUs and 87.0 percent among the DOs, a difference which is significant at the .05 level of analysis. These data would appear to show that acceptance of DMPA is facilitated in cases where the husband is in agreement with its use by his wife.

Table 13

Husbands role in R's DMPA use

\begin{tabular}{|c|c|c|c|c|}
\hline & Variables & $\begin{array}{c}\text { Continuing } \\
\text { Users }\end{array}$ & Drop-Outs & Total \\
\hline A. & $\begin{array}{l}\text { Whose initiative in deciding to use } \\
\text { DMPA } \\
\text { - largely R's own initiative } \\
\text { - largely husband's initiative } \\
\text { - joint initiative }\end{array}$ & $\begin{array}{c}27.7 \\
1.3 \\
71.0 \\
\end{array}$ & $\begin{array}{r}29.4 \\
1.9 \\
68.7 \\
\end{array}$ & $\begin{array}{r}28.6 \\
1.6 \\
69.8 \\
\end{array}$ \\
\hline B. & $\begin{array}{l}\text { Husband's feelings with regard to } \mathrm{R} \\
\text { receiving DMPA (1st survey) } \\
\text { - supportive from the beginning to } \\
\text { the present } \\
\text { - other } \\
\mathrm{X}^{2}(1 \mathrm{df})=19.5, \mathrm{p}<.00\end{array}$ & $\begin{array}{l}85.1 \\
14.9\end{array}$ & $\begin{array}{l}72.5 \\
27.5\end{array}$ & $\begin{array}{l}78.7 \\
21.3\end{array}$ \\
\hline C. & $\begin{array}{l}\text { Husband's reaction to R's decision } \\
\text { (2nd survey) } \\
\text { - supportive/agreeable } \\
\text { - not supportive/not agreeable } \\
\mathrm{X}^{2}(1 \mathrm{df})=4.2, \mathrm{p}<.04\end{array}$ & $\begin{array}{c}91.4 \\
8.6\end{array}$ & $\begin{array}{l}87.0 \\
13.0\end{array}$ & $\begin{array}{l}89.2 \\
10.8\end{array}$ \\
\hline D. & $\begin{array}{l}\text { Husband's knowledge about R's } \\
\text { DMPA status as of 2nd survey } \\
\text { - yes } \\
\text { - no }\end{array}$ & $\begin{array}{c}98.2 \\
1.8\end{array}$ & $\begin{array}{c}97.3 \\
2.7\end{array}$ & $\begin{array}{c}97.8 \\
2.2\end{array}$ \\
\hline
\end{tabular}




\section{HUSBAND-WIFE COMMUNICATION ABOUT FAMILY SIZE AND FP PRACTICE}

Husband-Wife Discussions Regarding Family Size. A little more than half of the DMPA acceptors ( 52.4 percent of CUs and 55.6 percent of DOs) claimed that they and their husbands had already talked about the number of children they would have even before they were married (Table 14). Most of these had held further discussions on this topic after their wedding as well. A little more than a fifth (23.0 percent) only broached the topic after their marriage while a similar proportion had never talked about it at all. Differences between the two groups on this variable were not statistically significant, as was also the case for the comparison on the question about plans for more children . Basically, a little less than twothirds of both groups would still like to have at least one more child (i.e. either the husband or the wife holds such a desire). This finding would appear to be reflective of the way in which Philippine society continues to value children, even as it moves toward a more urban and industrialized future. 
Table 14

Husband-Wife Communication Regarding Number of Children

\begin{tabular}{|c|c|c|c|c|}
\hline \multicolumn{2}{|r|}{ Variables } & \multirow{2}{*}{$\begin{array}{l}\begin{array}{l}\text { Continuing } \\
\text { Users } \\
\% \\
\\
\\
\\
21.7 \\
1.5 \\
25.9 \\
50.9\end{array}\end{array}$} & \multirow{2}{*}{$\begin{array}{c}\text { Drop-Outs } \\
\% \\
\\
\\
24.1 \\
1.9 \\
20.9 \\
53.7\end{array}$} & \multirow{2}{*}{$\begin{array}{c}\text { Total } \\
\% \\
\\
\\
\\
22.9 \\
1.7 \\
23.0 \\
52.3 \\
\end{array}$} \\
\hline A. & $\begin{array}{l}\text { R \& H talked about the number } \\
\text { of children they would have } \\
\text { - never } \\
\text { - before marriage only } \\
\text { - after marriage only } \\
\text { - both before and after marriage }\end{array}$ & & & \\
\hline B. & $\begin{array}{l}\text { R plans to have more children in } \\
\text { the future } \\
\text { - yes } \\
\text { - no }\end{array}$ & $\begin{array}{l}65.2 \\
34.8 \\
\end{array}$ & $\begin{array}{l}60.5 \\
39.5 \\
\end{array}$ & $\begin{array}{l}62.8 \\
37.2 \\
\end{array}$ \\
\hline C. & $\begin{array}{l}\mathrm{H} \text { interested in having more } \\
\text { children in the future } \\
\text { - yes } \\
\text { - no } \\
\mathrm{X}^{2}(1 \mathrm{df}), \mathrm{p}<.00\end{array}$ & $\begin{array}{l}62.7 \\
37.3\end{array}$ & $\begin{array}{l}52.0 \\
48.0\end{array}$ & $\begin{array}{l}57.3 \\
42.7\end{array}$ \\
\hline
\end{tabular}

Data from this survey show 57.3 percent of all husbands as compared to 62.8 percent of alll wives affirming their interest in having at least one more child. Somewhat surprisingly, the desire for an additional child is significantly higher among men married to continuing DMPA users than is true for the drop-outs.

Table 15 shows that there are few differences in the number of children desired by the CUs and the DOs (as well as among their husbands) at various points in time: (1) before marriage; (2) after marriage; and (3) in the future. In general, husbands are a little more likely than wives to want a large family (herein defined as four or more children). They would also like to have their next child at an earlier point in time. Again, though, we do not see any firm evidence that the continuing users are any more likely to desire a small number of children than the drop-outs. 
Table 15

Number of Children Wanted and When

\begin{tabular}{|c|c|c|c|c|c|c|c|}
\hline & & \multicolumn{2}{|c|}{$\begin{array}{c}\text { Continuing-Users } \\
\% \\
\end{array}$} & \multicolumn{2}{|c|}{$\begin{array}{c}\text { Drop-Outs } \\
\% \\
\end{array}$} & \multicolumn{2}{|c|}{$\begin{array}{c}\text { Total } \\
\% \\
\end{array}$} \\
\hline & & $\mathrm{R}$ & $\mathrm{H}$ & $\mathrm{R}$ & $\mathrm{H}$ & $\mathrm{R}$ & $\mathrm{H}$ \\
\hline A. & $\begin{array}{l}\text { Before marriage } \\
-2 \text { or below } \\
-3 \\
-4 \text { or more }\end{array}$ & $\begin{array}{c}28.2 \\
39.7 \\
32.1 \\
(\mathrm{n}=209) \\
\end{array}$ & $\begin{array}{c}27.3 \\
35.9 \\
36.8 \\
(\mathrm{n}=209) \\
\end{array}$ & $\begin{array}{c}32.8 \\
37.1 \\
30.1 \\
(\mathrm{n}=232) \\
\end{array}$ & $\begin{array}{c}28.0 \\
38.4 \\
33.6 \\
(\mathrm{n}=232) \\
\end{array}$ & $\begin{array}{c}30.6 \\
38.3 \\
31.1 \\
(\mathrm{n}=441)\end{array}$ & $\begin{array}{c}27.7 \\
37.2 \\
35.1 \\
(\mathrm{n}=441)\end{array}$ \\
\hline B. & $\begin{array}{l}\text { After marriage } \\
-2 \text { or below } \\
-3 \\
-4 \text { or more }\end{array}$ & $\begin{array}{c}31.0 \\
37.9 \\
31.1 \\
(\mathrm{n}=306) \\
\end{array}$ & $\begin{array}{c}30.4 \\
35.3 \\
34.3 \\
(\mathrm{n}=306) \\
\end{array}$ & $\begin{array}{c}31.8 \\
37.0 \\
31.2 \\
(\mathrm{n}=308) \\
\end{array}$ & $\begin{array}{c}29.3 \\
33.6 \\
37.1 \\
(\mathrm{n}=308) \\
\end{array}$ & $\begin{array}{c}31.4 \\
37.5 \\
31.1 \\
(\mathrm{n}=614) \\
\end{array}$ & $\begin{array}{c}29.8 \\
34.4 \\
35.8 \\
(\mathrm{n}=614) \\
\end{array}$ \\
\hline C. & $\begin{array}{l}\text { Future } \\
\text { - one more } \\
\text { - two or more }\end{array}$ & $\begin{array}{c}65.5 \\
34.5 \\
(\mathrm{n}=139)\end{array}$ & $\begin{array}{c}65.1 \\
34.9 \\
(\mathrm{n}=146)\end{array}$ & $\begin{array}{c}66.1 \\
33.9 \\
(\mathrm{n}=165)\end{array}$ & $\begin{array}{c}61.2 \\
38.8 \\
(\mathrm{n}=188)\end{array}$ & $\begin{array}{c}65.8 \\
34.2 \\
(\mathrm{n}=304)\end{array}$ & $\begin{array}{c}62.9 \\
37.1 \\
(\mathrm{n}=334)\end{array}$ \\
\hline D. & $\begin{array}{l}\text { When to have the } \\
\text { wanted children } \\
\text { - soon, within next } \\
2 \text { years } \\
\text { - after } 2 \text { or more } \\
\text { years }\end{array}$ & $\begin{array}{c}13.7 \\
86.3 \\
(n=139)\end{array}$ & $\begin{array}{c}19.5 \\
80.5 \\
(n=146)\end{array}$ & $\begin{array}{c}13.9 \\
86.1 \\
(\mathrm{n}=165)\end{array}$ & $\begin{array}{c}19.5 \\
80.5 \\
(n=188)\end{array}$ & $\begin{array}{c}13.8 \\
86.2 \\
(\mathrm{n}=304)\end{array}$ & $\begin{array}{c}19.5 \\
80.5 \\
(\mathrm{n}=334)\end{array}$ \\
\hline
\end{tabular}

Husband-Wife Discussions Regarding Family Planning. A significantly larger proportion of CUs (40.8 percent) compared to DOs (35.4 percent) claimed that they had only held husband-wife discussions about family planning on an "after marriage" basis (Table 16). In comparison, husband-wife discussions on this topic were more likely to occur both before and after marriage among the DOs. A very low percentage of couples bothered to discuss family planning together before marriage only while close to 20 percent had not yet gone into this topic. As a result of this pattern, it turns out that women who had already talked about FP before marriage are significantly overrepresented among the drop-outs. In addition, among those who talked about using FP after marriage, it was those who did so at 
a somewhat earlier date (i.e. before their second birth) who were more likely to drop-out. This seems to suggest that it was those who are least comfortable about FP discussions (i.e. those who postponed talking about this subject until after marriage or after they had already attained a fairly large family size) who are most likely to persevere in their use of DMPA. It could be that this group is somewhat less flexible and open to change than the DOs, a characteristic which in this case has worked to foster their continued allegiance to the injectables.

Once post-marital discussions are held about FP, it appears that those couples who initially focused their interest on either DMPA itself or some other modern method are significantly $(\mathrm{p}<10)$ more likely to remain a continuing user. Those who instead discussed a traditional method (withdrawal, rhythm, etc.) may still find themselves attracted to such approaches, thereby increasing their probability of eventually discontinuing DMPA.

A slight majority of women in both groups (57.5 percent of the CUs and 54.4 percent of the DOs) said that their last discussion of FP with their husband had concentrated largely on DMPA. The others said that they had talked about one or more alternative methods. 
Table 16

FP Discussions Before and After Marriage

\begin{tabular}{|c|c|c|c|c|}
\hline \multicolumn{2}{|c|}{ Variable } & \multirow{2}{*}{$\begin{array}{c}\text { Continuing } \\
\text { User } \\
\% \\
\\
\\
\\
20.7 \\
4.3 \\
40.8 \\
34.3 \\
(\mathrm{n}=397)\end{array}$} & \multirow{2}{*}{ 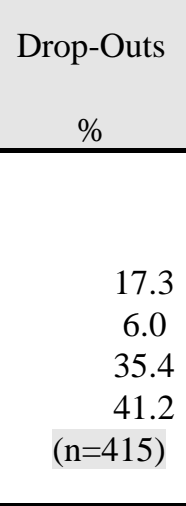 } & \multirow{2}{*}{$\begin{array}{l}\text { Total } \\
\begin{array}{c}\text { \% } \\
\\
\\
\\
19.0 \\
5.2 \\
38.1 \\
37.8 \\
(\mathrm{n}=812)\end{array}\end{array}$} \\
\hline A. & $\begin{array}{l}\mathrm{R} \& \mathrm{H} \text { talked about FP } \\
\text { - never } \\
\text { - before marriage only } \\
\text { - after marriage only } \\
\text { - both before and after marriage } \\
\mathrm{X}^{2}(3 \mathrm{df})=6.5, \mathrm{p}<.09\end{array}$ & & & \\
\hline B. & $\begin{array}{l}\text { Ever talked about FP before marriage? } \\
\text { - yes } \\
\text { - no } \\
\mathrm{X}^{2}(1 \mathrm{df})=6.3, \mathrm{p}<.01\end{array}$ & $\begin{array}{r}38.5 \\
61.5 \\
(\mathrm{n}=397) \\
\end{array}$ & $\begin{array}{r}47.2 \\
52.8 \\
(\mathrm{n}=415) \\
\end{array}$ & $\begin{array}{r}43.0 \\
57.0 \\
(n=812) \\
\end{array}$ \\
\hline C. & $\begin{array}{l}\text { Ever talked about FP after marriage? } \\
\text { - yes } \\
\text { - no }\end{array}$ & $\begin{array}{r}75.1 \\
24.9 \\
(\mathrm{n}=397) \\
\end{array}$ & $\begin{array}{r}76.6 \\
23.4 \\
(\mathrm{n}=415) \\
\end{array}$ & $\begin{array}{r}75.9 \\
24.1 \\
(\mathrm{n}=812) \\
\end{array}$ \\
\hline D. & $\begin{array}{l}\text { When talked about using FP after } \\
\text { marriage } \\
\text { - before 2nd pregnancy } \\
\text { - after 2nd and higher pregnancies } \\
\mathrm{X}^{2}(1 \mathrm{df})=2.7, \mathrm{p}<10\end{array}$ & $\begin{array}{r}37.3 \\
62.7 \\
(\mathrm{n}=252)\end{array}$ & $\begin{array}{r}44.3 \\
55.7 \\
(\mathrm{n}=273)\end{array}$ & $\begin{array}{r}41.0 \\
59.0 \\
(\mathrm{n}=525)\end{array}$ \\
\hline E. & $\begin{array}{l}\text { FP method talked about after marriage } \\
\text { - DMPA } \\
\text { - modern method } \\
\text { - traditional method } \\
\mathrm{X}^{2}(2 \mathrm{df})=4.5, \mathrm{p}<.10\end{array}$ & $\begin{array}{r}17.5 \\
65.9 \\
16.7 \\
(\mathrm{n}=252)\end{array}$ & $\begin{array}{r}15.3 \\
60.6 \\
24.1 \\
(\mathrm{n}=274)\end{array}$ & $\begin{array}{r}16.3 \\
63.1 \\
20.5 \\
(\mathrm{n}=526)\end{array}$ \\
\hline F. & $\begin{array}{l}\text { What was talked about } \\
\text { - DMPA } \\
\text { - other FP methods }\end{array}$ & $\begin{array}{r}57.5 \\
42.5 \\
(\mathrm{n}=313) \\
\end{array}$ & $\begin{array}{r}54.4 \\
45.6 \\
(\mathrm{n}=342) \\
\end{array}$ & $\begin{array}{r}55.9 \\
44.1 \\
(\mathrm{n}=655) \\
\end{array}$ \\
\hline
\end{tabular}




\section{OPINION ON DMPA HELD BY RELATIVES AND PEERS}

Discussions on DMPA with Family and Relatives. More than eight out of ten respondents discussed their use of DMPA with family members or relatives (Table 17). A large majority of these (80.5 percent of CUs and 76.7 percent of DOs) held this discussion with a sister or sister-in-law. A lower figure (47.8 percent of CUs and 44.7 percent of DOs) identified their mothers as a co-discussant while the proportions reporting their mother-in-law were even smaller (25.1 percent of CUs and 28.0 percent of DOs). As expected, male relatives were the least likely persons whom respondents would talk to about their use of DMPA.

Among those who talked about this matter with their relatives, 20.5 percent of the CUs and 29.1 percent of the DOs said they had encountered at least one such person who was not supportive of their DMPA use. In this case it was the DOs who were significantly more likely to have had such an experience. In general, the persons most likely to register such objections were found to be the respondent's mother, sister/sister-in-law and "other female relatives". The latter group played a particularly important role among the DOs whereas it was the mothers and the sisters or sisters-in-law who dominated among the CUs.

Discussions with Peers and Neighbors. Nearly 9 out of 10 respondents have spoken with their neighbors and friends about their DMPA use. DOs (32.3 percent) are more likely than CUs (23.6 percent) at the .01 level of significance to claim that their neighbors and friends were against their continued use of the method. They are also significantly more likely than the CUs (54.2 percent vs. 48.1 percent) to have heard of any opposition to DMPA. However, no significant differential exists as to the kind of persons they have heard talk against DMPA. 
Table 17

Opinion of Family Members, Relatives and Peers on DMPA

\begin{tabular}{|c|c|c|c|c|}
\hline \multicolumn{2}{|c|}{ Variables } & \multirow{2}{*}{$\begin{array}{l}\begin{array}{c}\text { Continuing } \\
\text { Users } \\
\%\end{array} \\
\\
\\
86.4\end{array}$} & \multirow{2}{*}{$\begin{array}{l}\text { Drop-Outs } \\
\begin{array}{r}\% \\
83.6\end{array}\end{array}$} & \multirow{2}{*}{$\begin{array}{l}\text { Total } \\
\% \\
85.0\end{array}$} \\
\hline A. & $\begin{array}{l}\mathrm{R} \text { has talked with family members or } \\
\text { relatives about DMPA injection }\end{array}$ & & & \\
\hline B. & $\begin{array}{l}\text { Whom R talked with (multiple responses) } \\
\text { - mother } \\
\text { - mother-in-law } \\
\text { - sister/sister-in-law } \\
\text { - other female relatives } \\
\text { - other male relatives }\end{array}$ & $\begin{array}{r}47.8 \\
25.1 \\
80.5 \\
37.3 \\
3.2 \\
(\mathrm{n}=343) \\
\end{array}$ & $\begin{array}{r}44.7 \\
28.0 \\
76.7 \\
38.0 \\
2.9 \\
(\mathrm{n}=347) \\
\end{array}$ & $\begin{array}{r}46.2 \\
26.5 \\
78.6 \\
37.7 \\
3.0 \\
(\mathrm{n}=690) \\
\end{array}$ \\
\hline C. & $\begin{array}{l}\text { Of the family and relatives } \mathrm{R} \text { talked with, } \\
\text { are there those who are opposed to DMPA? } \\
\text { - none } \\
\text { - yes } \\
\mathrm{X}^{2}(1 \mathrm{df})=6.9, \mathrm{p}<.01\end{array}$ & $\begin{array}{r}79.5 \\
20.5 \\
(n=342)\end{array}$ & $\begin{array}{r}70.9 \\
29.1 \\
(n=347)\end{array}$ & $\begin{array}{r}75.2 \\
24.8 \\
(\mathrm{n}=689)\end{array}$ \\
\hline D. & $\begin{array}{l}\text { Relatives who object/are not supportive of } \\
\text { R receiving DMPA } \\
\text { - mother } \\
\text { - mother-in-law } \\
\text { - sister/sister-in-law } \\
\text { - other female relatives } \\
\text { - other male relatives }\end{array}$ & $\begin{array}{r}30.0 \\
10.0 \\
30.0 \\
27.1 \\
2.9 \\
(\mathrm{n}=70)\end{array}$ & $\begin{array}{r}16.8 \\
13.9 \\
23.8 \\
41.6 \\
4.0 \\
(\mathrm{n}=101)\end{array}$ & $\begin{array}{r}22.2 \\
12.3 \\
26.3 \\
35.7 \\
3.5 \\
(\mathrm{n}=171)\end{array}$ \\
\hline E. & $\begin{array}{l}\mathrm{R} \text { has spoken to neighbors and friends } \\
\text { about her DMPA injection }\end{array}$ & 86.6 & 86.7 & 86.7 \\
\hline F. & $\begin{array}{l}\text { Opposing neighbors and friends to R's } \\
\text { DMPA use } \\
\mathrm{X}^{2}(1 \mathrm{df})=6.6, \mathrm{p}<.01\end{array}$ & 23.6 & 32.3 & 28.1 \\
\hline G. & $\begin{array}{l}\mathrm{R} \text { has heard of any opposition to DMPA } \\
\mathrm{X}^{2}(1 \mathrm{df})=3.0, \mathrm{p}<.08\end{array}$ & 48.1 & 54.2 & 51.2 \\
\hline H. & $\begin{array}{l}\text { Persons from whom R heard any } \\
\text { opposition to DMPA } \\
\text { - neighbors } \\
\text { - friends } \\
\text { - relatives } \\
\text { - others }\end{array}$ & $\begin{array}{r}52.4 \\
23.0 \\
13.6 \\
11.0 \\
(\mathrm{n}=191)\end{array}$ & $\begin{array}{r}51.1 \\
24.4 \\
16.0 \\
8.4 \\
(\mathrm{n}=225)\end{array}$ & $\begin{array}{r}51.7 \\
23.8 \\
14.9 \\
9.6 \\
(\mathrm{n}=416)\end{array}$ \\
\hline
\end{tabular}




\section{FINDINGS FROM THE MULTIVARIATE ANALYSIS}

The preceding bivariate analysis yielded several factors that are closely related with the continued use of DMPA. The simultaneous effects of these important variables will therefore be examined in this section through the use of logistic regression analysis. Worth mentioning at this point, though, is the fact that these variables are numerous and intercorrelated. Hence, it is necessary to determine which of them are the best predictors. The approach adopted in the present analysis is a purely quantitative strategy, namely, to subject them to a statistical selection process.

We thus ran separate logistic regressions for each of the main groups of important variables (contraceptive history, adoption of DMPA, quality of care, DMPA experience, husbandwife communication and social pressure). We tested for significant interactions between the variables which emerged significant from each regression. Of the three contraceptive history variables closely associated with DMPA continuation at the bivariate level (number of previous methods before DMPA adoption, length of use of first method used and kind of first method including DMPA), only the number of previous methods and the length of use remained significant. However, the number of previous methods and the length of use were highly correlated such that we opted for the number of previous methods as the contraceptive history variable to consider further in the modelling owing to its being a programmatic factor. Simultaneously considering the three important factors which influenced the adoption of the DMPA (timing of the decision, intention for using DMPA and time to reach the clinic), with the number of previous methods, none of these three factors remained significant.

In comparison, five of the many quality of care variables which were originally associated with DMPA continuation (properly informing $\mathrm{R}$ about the side effects of current/previous methods including DMPA, perception of the health provider as caring and courteous, asking 
$\mathrm{R}$ if she was breastfeeding a baby less than six weeks old, $\mathrm{R}$ being told about appetite loss, and $\mathrm{R}$ being advised to handle nausea, dizziness, headaches and weakness) were retained as strong determinants. Of the variables associated with R's management of DMPA side effects or her rating of DMPA in comparison to other methods, only action done on side effects experienced turned out to be significant within the multivariate context. Among all the previously significant factors associated with support (or lack of support) for DMPA use from significant others (husband, relatives/family members, friends and neighbors) it was only the husband's feelings with regard to the respondent's acceptance of DMPA that emerged significant. Finally, of the important factors related to husband-wife communication about family size and FP practice yielded by the bivariate analysis, only husband's interest in having more children in the future and discussion about FP before marriage persisted to be significant in the first-stage logistic regression.

These tedious modelling procedures reduced the number of significant factors to the point where they could now be examined simultaneously for strength of associations. We then considered simultaneously the ten factors emerging as significant in the preceding regressions. Interestingly enough, all ten variables remained significant. The model as a whole was also highly significant (chi-square=160.5 with 11 d.f., $\mathrm{p}<.001$ ). The final logit results -- coefficients, standard errors and odds ratios are shown in Table 18. 
Table 18

Logit Coefficients and Odds Ratios of Best Model to

Predict the Probability of Continuing DMPA

\begin{tabular}{|c|c|c|c|c|c|}
\hline & Factor & $\mathrm{N}$ & $\begin{array}{l}\text { Coefficien } \\
\mathrm{t}\end{array}$ & $\begin{array}{c}\text { Standard } \\
\text { Error }\end{array}$ & Odds Ratio \\
\hline A. & $\begin{array}{l}\text { Number of previous methods } \\
\text { before DMPA } \\
\text { - none } \\
\text { - one } \\
\text { - more than one } \\
\end{array}$ & $\begin{array}{l}217 \\
395 \\
200 \\
\end{array}$ & $\begin{array}{l}0.51 \\
0.45 \\
0.00 \\
\end{array}$ & $\begin{array}{l}0.22 \\
0.20 \\
-\quad \\
\end{array}$ & $\begin{array}{l}1.67 \\
1.57 \\
1.00 \\
\end{array}$ \\
\hline B. & $\begin{array}{l}\mathrm{R} \text { informed about possible side } \\
\text { effects of current/previous } \\
\text { methods } \\
\text { - yes } \\
\text { - no } \\
\end{array}$ & $\begin{array}{r}624 \\
188 \\
\end{array}$ & $\begin{array}{l}1.18 \\
0.00 \\
\end{array}$ & $\begin{array}{c}0.23 \\
188 \\
\end{array}$ & $\begin{array}{l}3.25 \\
1.00 \\
\end{array}$ \\
\hline C. & $\begin{array}{l}\text { Felt that patients are treated in a } \\
\text { caring and courteous way in the } \\
\text { health facility } \\
\text { - yes } \\
\text { - no }\end{array}$ & $\begin{array}{r}718 \\
94 \\
\end{array}$ & $\begin{array}{l}2.37 \\
0.00 \\
\end{array}$ & $\begin{array}{c}0.50 \\
- \\
\end{array}$ & $\begin{array}{r}10.70 \\
1.00 \\
\end{array}$ \\
\hline D. & $\begin{array}{l}\mathrm{R} \text { asked if breastfeeding a baby } \\
\text { less than } 6 \text { weeks old } \\
\text { - yes } \\
\text { - no }\end{array}$ & $\begin{array}{l}514 \\
298 \\
\end{array}$ & $\begin{array}{l}0.35 \\
0.00 \\
\end{array}$ & $\begin{array}{c}0.16 \\
- \\
\end{array}$ & $\begin{array}{l}1.42 \\
1.00 \\
\end{array}$ \\
\hline E. & $\begin{array}{l}\mathrm{R} \text { told about appetite loss } \\
- \text { - yes } \\
- \text { no }\end{array}$ & $\begin{array}{r}12 \\
800 \\
\end{array}$ & $\begin{array}{r}-1.49 \\
0.00 \\
\end{array}$ & $\begin{array}{c}0.71 \\
- \\
\end{array}$ & $\begin{array}{l}0.23 \\
1.00 \\
\end{array}$ \\
\hline F. & $\begin{array}{l}\mathrm{R} \text { advised on how to handle } \\
\text { nausea, dizziness, headaches, } \\
\text { weakness } \\
\text { - yes } \\
\text { - no, not applicable }\end{array}$ & $\begin{array}{l}299 \\
513 \\
\end{array}$ & $\begin{array}{l}0.44 \\
0.00 \\
\end{array}$ & $\begin{array}{c}0.17 \\
- \\
\end{array}$ & $\begin{array}{l}1.55 \\
1.00 \\
\end{array}$ \\
\hline G. & $\begin{array}{l}\text { Action done on side effects } \\
\text { experienced } \\
\text { - followed provider's advice, } \\
\text { returned to clinic, others } \\
\text { - none, not applicable }\end{array}$ & $\begin{array}{r}213 \\
599 \\
\end{array}$ & $\begin{array}{r}-0.42 \\
0.00 \\
\end{array}$ & $\begin{array}{r}0.18 \\
- \\
\end{array}$ & $\begin{array}{l}0.66 \\
1.00 \\
\end{array}$ \\
\hline H. & $\begin{array}{l}\text { Husband's feelings with regard to } \\
\mathrm{R} \text { receiving DMPA } \\
\text { - supportive } \\
\text { - not supportive }\end{array}$ & $\begin{array}{l}639 \\
173 \\
\end{array}$ & $\begin{array}{l}0.90 \\
0.00 \\
\end{array}$ & $\begin{array}{c}0.20 \\
- \\
\end{array}$ & $\begin{array}{l}2.46 \\
1.00 \\
\end{array}$ \\
\hline I. & $\begin{array}{l}\text { H interested in having more } \\
\text { children in the future } \\
\text { - yes } \\
\text { - no }\end{array}$ & $\begin{array}{l}465 \\
347 \\
\end{array}$ & $\begin{array}{l}0.45 \\
0.00 \\
\end{array}$ & $\begin{array}{c}0.16 \\
- \\
\end{array}$ & $\begin{array}{l}1.57 \\
1.00 \\
\end{array}$ \\
\hline J. & $\begin{array}{l}\text { Ever talked about FP before } \\
\text { marriage? } \\
\text { - yes } \\
\text { - no }\end{array}$ & $\begin{array}{l}349 \\
463\end{array}$ & $\begin{array}{c}-0.52 \\
0.00\end{array}$ & $\begin{array}{c}0.16 \\
-\end{array}$ & $\begin{array}{l}0.59 \\
1.00\end{array}$ \\
\hline
\end{tabular}


As stated earlier, the number of methods used before DMPA represents the lone significant contraceptive history variable entered into the final model. Holding constant the effects of the other important variables, acceptors with no previous experience of FP are about 1.67 times as likely to continue DMPA use compared to those who have had more than one previous method before DMPA. Those who have experienced one method before DMPA also had continuation rates which were 1.57 times higher in comparison to those with experience of more than one method.

The best fitting model revealed five significant quality of care variables. All other things being equal, if the DMPA acceptor was informed about the possible side effects of current FP methods, (including DMPA or other previous methods) she would be 3.25 times more likely to continue her DMPA use, In the same way, if the respondent feels that patients were treated in a caring and courteous manner in the health facility, she will be 10.7 times more likely to continue DMPA. For respondents who were asked if they were breastfeeding a baby less than six weeks old before the provider gave DMPA, the probability of DMPA continuation is 1.42 as great as for those who were not asked this question. While telling acceptors about appetite loss reduced the probability of DMPA continuation by 77 percent, advising them on how to handle nausea, dizziness, headaches and weakness increased the continuation rate by 55 percent.

As was discovered in the bivariate analysis, the multivariate logistic model indicates that acceptors who followed the provider's advice or who returned to the clinic were less likely (34 percent) to continue DMPA use compared to those who either did nothing about DMPA side effects or who did not experience any DMPA side effects at all. Controlling for the confounding effects of the other important factors, the proportion of continuing DMPA acceptors whose husbands are supportive of their DMPA use is about 2.46 times that of DMPA acceptors whose husbands are not supportive.

Two significant factors from the group of variables indicate husband-wife communication about family size and FP practice. Those whose husbands were interested in having more children in the future are 1.57 times more likely to continue DMPA use than those whose 
husbands were not interested in having more children in the future. This seems to indicate that DMPA is being used more for spacing purposes than to limit or terminate childbearing.

Husband-wife discussion about FP before marriage tends to reduce DMPA continuation by 41 percent. As noted in the bivariate analysis section, this finding suggests that it was those who postponed talking about this subject until after marriage or after they had attained a fairly large family size, who were most likely to remain DMPA continuing-users.

The above findings are for a final logistic regression model which was built by initially considering all factors which were significantly associated with DMPA continuation status at the bivariate level. A possible criticism which might be raised against this approach is that it has failed to incorporate any of the standard social and economic factors which are usually considered as major determinants of fertility and family planning. This occurred in the present case, of course, because none of these variables were found to significantly differentiate, at the bivariate level, between continuing users and drop-outs.

Nonetheless, the theoretical importance of many of the socioeconomic variables led us to incorporate four of these factors into the analysis. We thus re-ran the final model after including the following factors: age of the mother, mother's religion (Catholic vs. nonCatholic), mother's education and mother's labor force status (whether or not the respondent was currently "doing anything to earn income").

The results of this exercise served only to confirm the findings presented in Table 18. None of the four socioeconomic variables was found to be a significant correlate (even at .10) of continued DMPA use (figures not shown). All other variables in the model retained their status as significant determinants of the dependent variable, all at .05 and with no changes in the direction of the original relationships.

We may therefore summarize this section of the report by referring again to the major conclusions implicit in Table 18. Briefly, continued use of DMPA seems to be facilitated 
by several factors including a rather limited previous use of FP, the provision of proper information about side effects, the perception that providers are willing to treat their clients in a caring/courteous way, the provider's willingness to ask the full round of DMPA prescreening questions, counselling and guidance on most side effects, husband's support for the use of DMPA and husband's desire for more children. On the other hand, telling acceptors about appetite loss, going back to the clinic to seek help on side effects, and husband-wife discussion about FP before marriage seem to inhibit in some way the continued use of DMPA. 


\section{SUMMARY, CONCLUSIONS, AND IMPLICATIONS}

In 1994, the Population Council, Manila undertook an OR project entitled the DMPA Monitoring and Follow-up Studies. This report focuses on the survey component of this project with the main aim of examining comprehensively the influence on continued DMPA use of socioeconomic, demographic and reproductive history variables, as well as of factors surrounding the R's decision to use DMPA, quality of care factors, and the influence of significant others (husband, other family members, relatives and friends).

\section{Method of Analysis and Data Source}

Bivariate and multivariate analyses have been presented, as based on a sample of 812 women drawn to represent the DMPA acceptors in nine LGUs where the first phase of the DMPA Reintroduction Program was implemented in 1994. These sample DMPA acceptors were surveyed twice--in February and then again in June-July 1995--to document their experience with and perceptions of DMPA since their first injection. The analyses concentrated on the eight major areas: (1) socioeconomic and demographic characteristics; (2) reproductive history; (3) contraceptive history; (4) adoption of DMPA; (5) quality of care related to DMPA; (6) R's experience with DMPA; (7) husband-wife communication regarding family size and FP practice; and (8) attitudes towards DMPA held by relatives and friends.

\section{Socioeconomic and Demographic Characteristics, Marital and Reproductive Histories}

There were no significant associations involving DMPA continuation rates and any of the socioeconomic, demographic, marital history or reproductive history variables. On the average, most DMPA acceptors and their husbands were born in rural areas, were Roman Catholics and had at least a high school education. While a majority were not currently 
working, those who were employed were earning a median income of P1000 per month with most of them self-employed. Almost all the husbands were currently working and earning median of P2,500 per month from a blue collar or farming type of occupation. The average DMPA acceptor was 29 years old and already married by age 20, while her husband was presently 32 years old. The average number of living children and of pregnancies was three. A fourth of the respondents had experienced at least one abortion, whether spontaneous or induced.

While the above-mentioned variables appeared to have no relationship with DMPA continuation, it could nonetheless prove helpful for program managers to know the basic characteristics of women who have accepted DMPA for the first time. Moreover, the finding that about 10 percent accepted DMPA despite their having given birth to only one child indicates that the stipulation of providing DMPA to women with at least two children has not been uniformly complied with. This stipulation needs to be clarified to both providers and clients.

Furthermore, about three percent of drop-outs were found to be currently pregnant as of the first follow-up study. This figure may include women who were pregnant at the time they received DMPA. Should this in fact be true it demonstrates the need for stricter procedures in pre-screening so as to insure that no pregnancy is present prior to dispensing DMPA. (Indeed, about a third of the respondents to this survey claimed that their DMPA provider had never asked them if they were pregnant or experiencing an overdue menstrual period.)

\section{Contraceptive History}

A large number of contraceptive history variables were considered, including (1) the number of previous methods used before DMPA; (2) type of first FP method; (3) pregnancy interval in which a FP method was first used; (4) duration of first FP method used; (5) reason for discontinuing first FP method; (6) type of most recent/last FP method used before DMPA; (7) duration of most recent/last FP method used; and (8) reason for discontinuing most 
recent/last FP method. Among these factors only the first, second and fourth emerged significant at the bivariate level of analysis.

However, when these three variables were taken simultaneously with other important variables, only the number of previous methods used before DMPA and the duration of first method used remained important. (Insofar as these two variables were significantly associated with each other, the number of previous methods used before DMPA was considered to represent the contraceptive history variable.) Holding constant the effects of other factors, the proportion of continuing acceptors with no previous experience of FP prior to receving DMPA is higher than those with more than one method. Stated differently, those who tended to discontinue DMPA were those who had a shorter duration of first method because of their tendency to shift to other methods. One program implication of these findings is the need for service providers to offer high quality care to their clients in order to lessen the probability that she will shift to another method. Having once taken this step for the first FP method ever used, she may be psychologically prone to immediately repeat the whole discontinuation experience again once she has started to use DMPA.

\section{Adoption of DMPA}

The fourteen intervening factors which were hypothesized as having influenced R's decision to use DMPA were: (1) the number of sources of DMPA information; (2) R's most influential source of DMPA information; (3) positive or negative aspects of DMPA learned by R; (4) whether information was given about DMPA only or about DMPA with other methods; (5) other contraceptive methods for which information was given; (6) whether R was given IEC materials on FP; (7) ways of promoting DMPA over other methods by the service provider; (8) whether R was given extra encouragement to choose DMPA over other methods; (9) timing of the decision to adopt DMPA; (10) husband's knowledge about R's use of DMPA; (11) reasons for choosing DMPA over other methods; (12) intention for using DMPA; (13) accessibility to the health facility; and (14) time spent in reaching the health 
facility.

Only three of these variables turned out to be significant at the bivariate level. These were, first, the timing of the decision to adopt DMPA (whether immediately, within two weeks, or after more than two weeks); secondly, the intention for using DMPA (whether to delay pregnancy or to stop childbearing altogether); and third, the time required to reach the health facility. When these three factors were simultaneously considered, only the latter one was found to be significant. Further still, even this factor (time to reach the clinic) was reduced towards statistical insignificance once all the variables in the final logit model (e.g. contraceptive history, quality of care, husband and social pressure variables) were controlled for statistically. Overall, then, these factors were not as important as the other groups of variables in predicting continued use of DMPA. Hence, they may be regarded as being of low priority in the implementation of the DMPA program.

\section{Quality of Care Related to DMPA Use}

The variables examined which pertain to quality of care fall under four sub-groups: (1) provision of DMPA for the first time; (2) R's rating of the health provider; (3) screening questions asked before giving DMPA; and (4) counselling and guidance on DMPA side effects.

Specific indicators included within the first sub-group were: (a) type of provider administering the first DMPA injection; (b) prior acquaintance between the DMPA provider and client; (c) timing of the first DMPA injection; (d) whether or not R was told about possible side effects from the DMPA injection; (e) expenses incurred for the DMPA injection; and (f) whether or not R was told the time to return for a check-up. Only two of these were initially able to significantly differentiate CUs from DOs. These were, first, the provision of information on side effects prior to giving DMPA and, secondly, telling clients to return for a check-up. When these were subsequently examined within the multivariate 
context, only the provision of information on side effects remained to be significantly associated. This emphasizes again the importance of providing balanced information in convincing DMPA acceptors to continue using the method even after a side effect has been manifested. Insofar as other OR Studies on FP drop-outs in the Philippines have reached an essentially similar conclusion (e.g. Palma-Sealza, 1993), we believe that this guideline should be given particular importance by program managers.

Also worth stressing at this point is the apparent omission by service providers in providing DMPA in accordance with the prescribed schedule: i.e., during the first seven days after the beginning of menstruation; within the first 28 days after a delivery if the woman is not breastfeeding or within two weeks after an abortion. About 39 percent of CUs and 45 percent of DOs were not given their DMPA in accordance with this schedule, thus indicating that the quality of care being given in public sector health facilities is as yet in need of improvement.

The second subgroup of quality of care factors deals with the respondent's rating of the health provider. These included (a) the friendliness and approachableness of the provider; (b) competence of the provider; (c) R's perception as to whether or not patients are treated in a caring and courteous manner in the health facility; (d) client follow-up since receiving DMPA; (e) client follow-up during the two months preceding the survey; and (f) whether the client had been informed about FP during her most recent visit. All except the last two indicators were significant in the bivariate analysis. However, when each of the interpersonal relationships variables was separately subjected to the multivariate modeling procedures, only R's perception on the extent to which patients are treated in a caring and courteous way consistently retained its significance. This may therefore be the best measure to represent interpersonal relationships in the present study. That is, all other things being equal, if the respondent feels that patients are treated in a caring and courteous manner, the more likely she will be to continue her DMPA use. The importance of fostering close interpersonal relationships between the provider and client is therefore clearly suggested by this finding. 
A variety of screening questions pertaining to the client's medical and reproductive history constituted the third sub-group of quality of care factors. Bivariate analysis revealed all but two of these (asking about the client's history of blood clotting/heart problems and about her contraceptive history) were significantly associated with the dependent variable in this case. However, only the question on whether $\mathrm{R}$ was breastfeeding a baby less than six weeks old retained its significance during the multivariate analyses. In general, it appears that asking the full-range of screening questions prior to giving DMPA can be an effective strategy for bringing down DMPA discontinuation rates.

The last sub-group of quality of care variables related to counselling and quidance on DMPA side effects. These included several specific side effects of DMPA including (a) weight gain; (b) appetite loss; (c) nausea, dizziness, headaches, weakness; (d) heavy bleeding; (e) nonbleeding or less than usual bleeding/amenorrhea; and (f) spotting. We have already seen that the provision of information about side effects (in general) associated with DMPA can bear a significant association with continuation status. In this case, though, the statistical analysis of the role played by specifically informing clients about each of these side effects and guiding them on the manner in which each of these can be handled did not reveal striking insights. On the one hand, those who had been counselled on how to handle nausea, dizziness, headaches and weakness were significantly less likely to discontinue DMPA use. This was offset, however, by the unexpected finding that those who had been told that they might experience appetite loss were actually more likely to become drop-outs, even when all other key factors were controlled in the logit analysis.

\section{Respondents' Experience with DMPA}

The first of four factors dealing with the respondent's experience with DMPA dealt with the question of physical side effects. Somewhat surprisingly, no significant variations between the CUs and DOs were observed in this case except on weight gain and appetite loss and for

the the action taken in response to the side effects which were experienced. A significantly higher proportion of CUs (48 percent) than of DOs (39 percent) experienced weight gain, 
a side effect which at least does not involve discomfort or fear about some resulting illness. In contrast, more DOs than CUs ( 8 percent vs. 4 percent) reported appetite loss. While a significantly higher proportion of DOs did something about their side effects, either by following the provider's advice or by returning to the clinic, the advice given on these occasions (e.g. that the symptoms were "normal" and "nothing to worry about") appeared to not be very helpful in preventing method discontinuation. This latter finding is important since it persisted, even after multivariate staistical controls had been put in place. What this implies is the need to pay more attention to those returning acceptors and to better meet their needs, whatever these might be. Better explanations and more helpful advice in handling specific side effects are especially needed at this point. Indeed, counselling on side effects management should be a high-priority area for program upgrading.

The next factor to be investigated dealt with emotional changes. The most frequent response in this case concerned the tendency for DMPA users to easily become angry. In general, though, the presence or absence of this factor did not seem to influence the probability that DMPA use would be long sustained.

Several questions asked the respondents to compare DMPA with other methods. Specific comparisons involved the length of time $\mathrm{R}$ intended to use DMPA, her willingness to recommend DMPA to relatives and friends and her reasons for recommending DMPA. All of these variables were significant in the bivariate analysis but not in the multivariate context.

Husband's support of his wife's decision to adopt DMPA was a highly significantly predictor of DMPA continuation rates at both the bivariate and multivariate levels of analysis. Hence, innovative ways should be developed to help husbands take a positive attitude towards family planning. For example, it may be helpful to develop IEC materials for husbands since they are less likely to visit the health facility and to have frequent contact with the health provider. It might help as well to recruit more men to serve as FP outreach workers, a strategy that has met with some success in other contexts (e.g. Foreit $\underline{\text { et }} \underline{\text { al, }}$ 1992). 


\section{Husband-Wife Communication about Family Size and FP Practice}

The husband's desire for more children, discussion about family planning in general both before and after marriage and talking about using a family planning method after marriage were all found to be significantly associated with DMPA use within the bivariate context. However, husband's desire for more children and discussion about family planning before marriage were able to retain their significance once the other important variables were simultaneously considered. For some reason, discontinuation rates are lower for women with husbands who wish to have at least one more child in the future. Also somewhat surprising is the finding that continuation rates are inversely correlated with the experience of having talked about FP before marriage.

\section{Opinion on DMPA Held by Relatives and Peers}

The opposition of either close relatives (mothers, sisters or female relatives) or neighbors and friends to DMPA was found to be closely associated with the decision to discontinue DMPA use when considered at the bivariate level. However, when the other important variables were taken simultaneously these factors were no longer significantly correlated.

\section{Conclusion}

On the whole, out of the many variables examined, limited or no previous FP use before adopting DMPA, the presence of a supportive husband and husband's desire for more children, warm interpersonal relations between providers and clients, the provision of appropriate information about side effects and resort to proper pre-screening questions prior to dispensing DMPA all stood out as important facilitating factors in the decision to continue using DMPA. By paying greater attention to male outreach activities and to quality of care in FP provision, program managers should be able to increase the adoption and continued 
use of this important new addition to the Philippine Family Planning Program. 


\section{REFERENCES}

Arenas, Myra and Marilou Palabrica-Costello. 1995. Experience with the DMPA Injectable Contraceptive: A Comparison between Continuing Users and Drop-outs. Manila: The Population Council. September 1995.

Bruce, Judith. "Fundamental Elements of the Quality of Care: A Simple Framework" Studies in Family Planning. Vol.21 No.2. March/April 1990.

Foreit, James R., et al. 1992. "A Comparison of the Performance of Male and Female CBD Distributors in Peru." Studies in Family Planning 23: 58-62.

Guilleband, J., 1985. Contraception: Your Questions Answered. New York: Pitman.

Hatcher, Robert A., et al. 1994. Contraceptive Technology. 16th Revised Edition. New York: Irvington Publishers.

Lee, Nancy C., Herbert B. Peterson, and Susan Y. Chun. 1989. "Health effects of Contraception." In Contraceptive Use and Controlled Fertility: Health Issues for Women and Children. National Academy of Sciences. Washington,DC: Natioanl Academy Press.

Liskin, Laurie, Richard Blackburn, and Rula Ghani. 1987. "Long-acting Progestins: Promise and Prospects." Population Report Series K(3).

Palma-Sealza, Lita. 1993. "Quality of Care and Family Planning Drop-outs in Bukidnon Province, Philippines." Philippine Population Journal.

Patron, Carmela and Marilou Palabrica-Costello. 1995. Experience with the DMPA Injectable Contraceptive: Findings from a Survey of DMPA Acceptors. Manila: The Population Council. September 1995.

Reynes, Josefina F. 1980. "The Depo-Provera Program in Bohol: January 1,1978 December 31,1979". Bohol Province MCH/FP Project. Research Note Number 75, Bohol Province MCH/FP Project.

Riley, Ann P., M Kathryn Stewart, and Jyotsnamoy Chakraborty. 1994. Program and Method-Related Determinants of First Use Duration in Rural Bangladesh. Studies in Family Planning. Vol. 25 No. 5. September/October 1994.

Younis, Nabil, et al. 1993. "A Community Study of Gynecological and Related Morbidities in Rural Egypt." Studies in Family Planning 24: 175-186. 